\title{
Archaeological Services Associated with the Perrin Family Gravesite on Perrin-Beitel Road, San Antonio, Bexar County, Texas
}

Jason D. Weston

Follow this and additional works at: https://scholarworks.sfasu.edu/ita

Part of the American Material Culture Commons, Archaeological Anthropology Commons, Environmental Studies Commons, Other American Studies Commons, Other Arts and Humanities Commons, Other History of Art, Architecture, and Archaeology Commons, and the United States History Commons

Tell us how this article helped you.

This Article is brought to you for free and open access by the Center for Regional Heritage Research at SFA ScholarWorks. It has been accepted for inclusion in Index of Texas Archaeology: Open Access Gray Literature from the Lone Star State by an authorized editor of SFA ScholarWorks. For more information, please contact cdsscholarworks@sfasu.edu. 


\section{Archaeological Services Associated with the Perrin Family Gravesite on Perrin- Beitel Road, San Antonio, Bexar County, Texas}

\section{Creative Commons License}

\section{(c) (1) (8)}

This work is licensed under a Creative Commons Attribution-NonCommercial 4.0 International License 


\title{
Archaeological Services Associated with the Perrin Family Gravesite on Perrin-Beitel Road, San Antonio, Bexar County, Texas
}

\author{
Jason D. Weston
}

Center for Archaeological Research

The University of Texas at San Antonio

Archaeologcial Survey Report, No. 339

2003
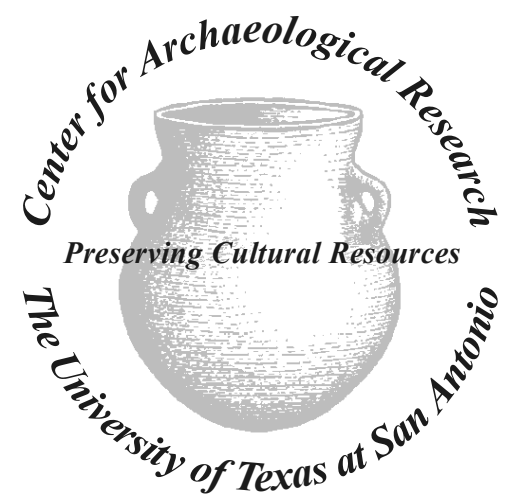


\title{
Archaeological Services Associated with the Perrin Family Gravesite on Perrin-Beitel Road, San Antonio, Bexar County, Texas
}

\author{
Jason D. Weston
}

Principal Investigator

Steve A. Tomka

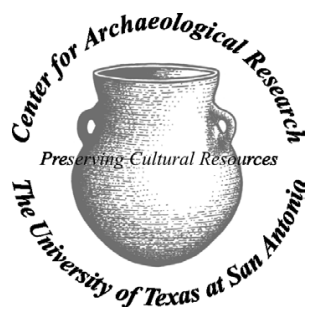

Center for Archaeological Research

The University of Texas at San Antonio

Archaeological Survey Report, No. 339

(C)2003 
A list of publications offered by the Center for Archaeological Research is available. Call (210) 458-4378; write to the Center for Archaeological Research, The University of Texas at San Antonio, 6900 N. Loop 1604 W., San Antonio, Texas 78249-0658; e-mail to car@lonestar.utsa.edu; or visit CAR's web site at http://car.utsa.edu. 


\section{Abstract:}

Under contract with Mr. Harry Affleck of San Antonio, the Center for Archaeological Research (CAR) performed archaeological services on the property located at 9501/9505 Perrin-Beitel Road in central San Antonio. The property is the site of the Perrin Family Gravesite and will be impacted by the construction of a self-storage unit and associated improvements. Archaeological services were performed between January and March 2003 and involved archival research to compile information on the history of the Perrin Family Gravesite and fieldwork to establish the location of all burials present on site.

Archival research resulted in the compilation of a history of use of the Perrin Family Gravesite. Fieldwork consisted of a ground penetrating radar survey, hand excavations, and mechanical scraping. At the inception of fieldwork, nine headstones accounting for ten interments were visible on surface. However, it was not known how many, if any, of the headstones were in their original resting places. Also, it was suspected that at least one of the headstones had no known associated grave. Fieldwork identified ten graves on the site and documented some degree of displacement of the headstones since their original placement. The known locations of all burials within the Perrin Family Gravesite should provide sufficient information to erect a buffer to protect the interments from impact from construction activities. 


\section{Table of Contents:}

Abstract
Figures
Tables scknowledgments
Introduction
Project Area
Methodology
Results os Archival Investigations
Fieldwork and Results of Investigations
Conclusions and Recommendations
References Cited
Appendix A: Headstone Photographs
Appendix B: Boring Logs Reproduced from Arias and Kezar Geotechnical Report
Appendix C: Survey of Perrin Family Gravesite Tract conducted by Pape-Dawson Engineers




\section{Figures:}

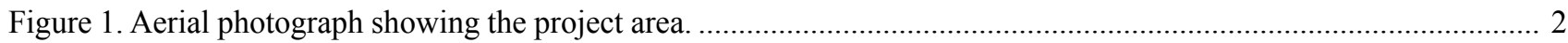

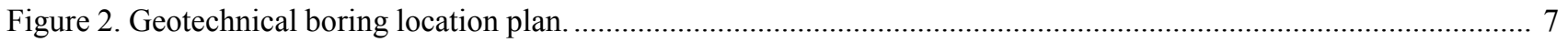

Figure 3. Site map showing locations of all excavations and iron pins. ........................................................................ 8

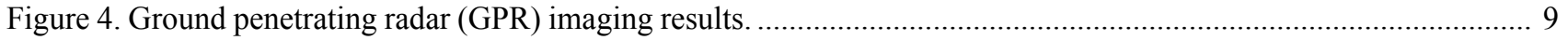

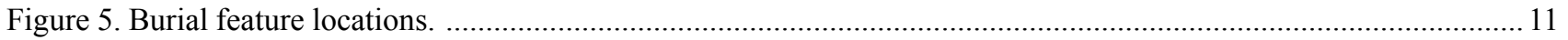

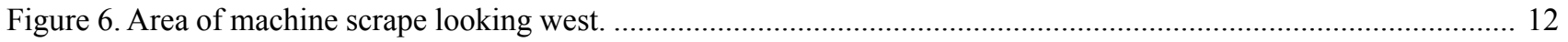

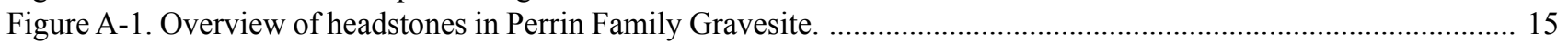

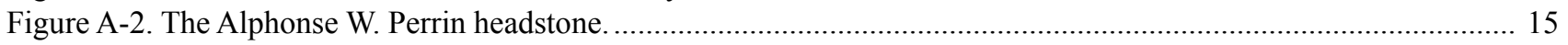

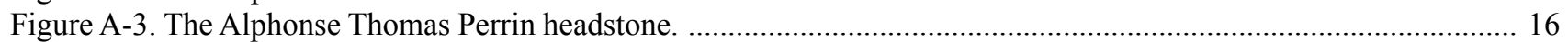

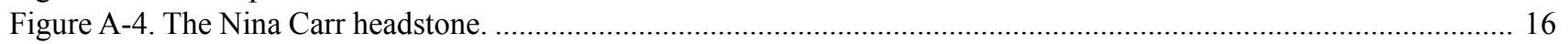

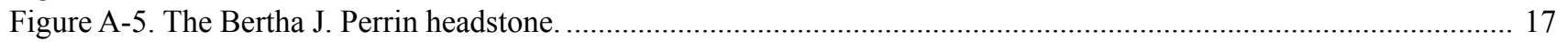

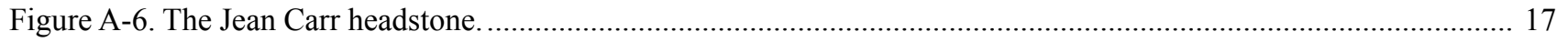

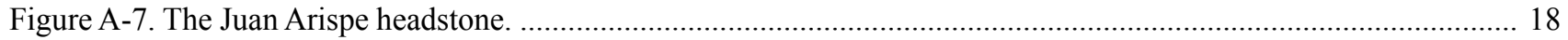

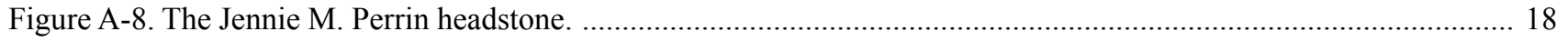

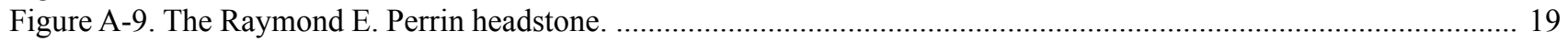

Figure A-10. The Francis A. and Frances P. McClure headstone. ……................................................................... 19

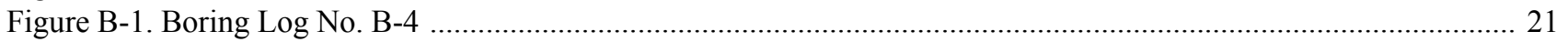

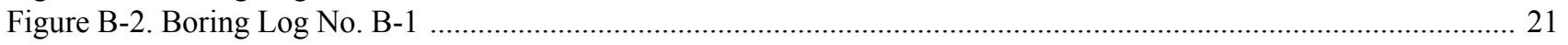

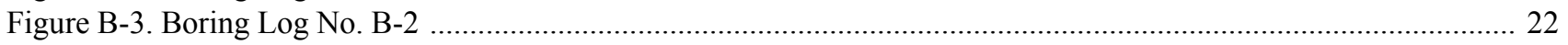

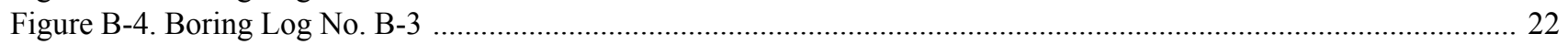

\section{Tables:}

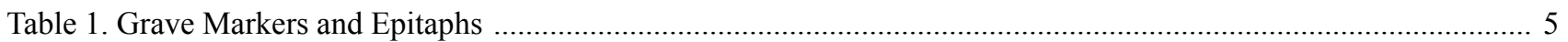

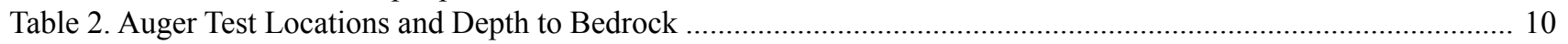




\section{Acknowledgments:}

First and foremost, Mr. Harry Affleck is to be commended for his care and concern for the well being of the Perrin Family Gravesite and his amicable cooperation and patience. The author also would like to thank Mr. Breese Morse of Artistic Builders, Inc., project superintendent, for his assistance and cooperation. Thanks also go to Herb Uecker of the City of San Antonio Historic Preservation Office for his assistance during the preliminary phase of this project. Appreciation also goes to Alyson Ponomarenko for the operation of the ground penetrating radar and her interpretations of the data. The hard work of CAR field personnel Bruce Moses, Stacy Wagner and Matthew Senn is also greatly appreciated. Thanks also go to Dr. Raymond P. Mauldin and Dr. Steve A. Tomka for their assistance in all phases of the project. Last but not least, a great deal of appreciation to Bruce Moses for the quality drafting and to Johanna Hunziker and Donna Edmondson for editing the final report. 


\section{Introduction}

The Center for Archaeological Research (CAR) of The University of Texas at San Antonio was contracted by Mr. Harry Affleck of San Antonio to perform archaeological services on the property located in the 9500 block of Perrin-Beitel Road in northeast San Antonio. At the time of the fieldwork, the property was the construction site of a planned self-storage unit and associated facilities.

Artistic Builders, Inc., the construction company hired by Mr. Affleck, was in the process of site preparation when the City of San Antonio Historic Preservation Office (SAHPO) temporarily suspended the construction permit. Immediately prior to this decision, the SAHPO had been informed by descendants of the Perrin family that the tract of land under construction contained the Perrin family graves. It was suspected that in addition to the nine marked graves there may be at least one unmarked grave on the property. Furthermore, it was suspected that the nine headstones in the cemetery were no longer in their original positions.

Since it could not be assumed that the headstones, in their present locations, marked the exact locations of graves, and given the possibility that an unmarked grave may be present on site, archaeological services were required to establish the number of burials and their exact locations.

The specific goals of the archival and archaeological investigations were to

1) Compile available archival information on the family cemetery;

2) Establish whether the headstones mark the precise locations of graves; and

3) Locate all graves within the property and mark them for future planning purposes.

Although some development is planned west of the line of gravestones, the intention is to protect all graves associated with the Perrin Family Gravesite.

\section{Project Area}

The project area is located at $9501 / 9505$ Perrin-Beitel Road (Figure 1). The property is officially described as covering 0.7765 acres, more or less, being Lot 20, Block 5, New City Block 13993, SKLENCAR SUBDIVISION, in the City of San Antonio, Bexar County, Texas, according to plat thereof recorded in Volume 9517, Page 166, Deed and Plat Records of Bexar County, Texas. The 34,480-square-foot property, which fronts onto PerrinBeitel Road, is a long and narrow strip measuring 431 feet by 80 feet. At the time of the first visit (16 January 2003), the front two-thirds of the property, approximately 330 feet by 80 feet, had been graded and subsequently filled with caliche/limestone gravel. Discussions with the project superintendent indicated that approximately $1.0-1.5$ feet of black clay had been bladed from this area and approximately 2 feet of fill was deposited on top. The 100 foot by 80 foot area along the back (west) end of the property had been bladed to a depth of approximately 6-12 inches in all but a small, approximately 30 foot by 25 foot area in front of the nine headstones, representing ten burials. Eight of the headstones were lined up in a north-south direction. The ninth was 1.35 meters to the east in the center of the area. This headstone appears to have been moved at least once and was not in its original location.

\section{Methodology}

To accomplish the goals of the project, it was decided that archival research would be used to compile information on the use-history of the cemetery. In addition, a ground penetrating radar (GPR) survey was to be used to identify all subsurface disturbances starting with those assumed to be in the vicinity of the headstones. The ground-truthing of the signals from the GPR survey would be conducted using hand excavated $50-x-50-\mathrm{cm}$ exploratory units and/or $50-\mathrm{cm}$ wide trenches. If these techniques were not sufficient to locate all graves, it was recommended that the area surrounding the headstones be bladed in 2-3 inch thick layers to expose the outline of any unmarked grave(s). 


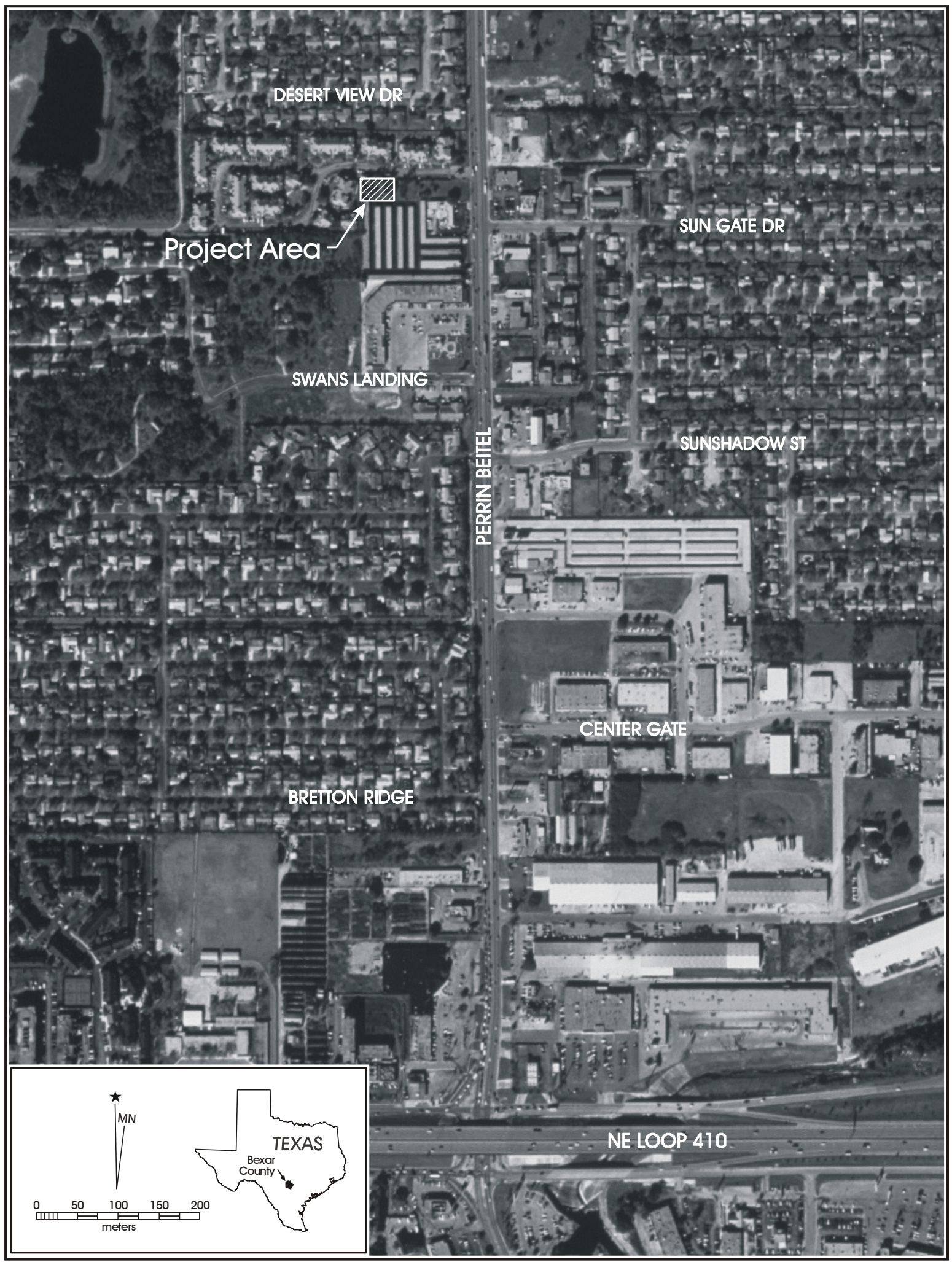

Figure 1. Aerial photograph showing the project area. 


\section{The Archival Research}

Various records and research on the history of the Perrin Family Gravesite has been compiled by descendants of the family and by Mr. Tim Swan (a former student of Baylor University) and Mr. Tom Wilson (former member of the Bexar County Historical Commission). It is not known how systematic and comprehensive this background research is. Likewise, none of the previous studies sought to establish the precise locations of the known gravesites within the property. To augment the existing data, systematic archival research was undertaken in an effort to corroborate and clarify the information available on the cemetery. The main objectives of this research was to establish the use-history of the cemetery, corroborate the number of individuals buried in the cemetery and on the property, define the number of headstones, and if possible, their exact original locations.

\section{Ground Penetrating Radar (GPR) Survey}

Originally, it was proposed that ground penetrating radar be employed to define radar signatures of the suspected graves in the vicinity of the headstones. Using these signatures as a basis, the remaining property would be surveyed to identify similar radar signatures away from the headstones. It was hoped that these outlier signatures could potentially correspond to the location of isolated burials on the property.

Ground penetrating radar is an instrument that, under appropriate soil conditions, can be effectively used to identify subsurface anomalies such as prehistoric hearth features, buried irrigation canals, and other buried pits such as grave shafts. Under normal conditions, the radar waves identify subsurface anomalies (i.e., linear patterns, systematically repeating patterns such as graves lined up in a row) that are regularly patterned and may have a low probability of being randomly generated by natural phenomena. Archaeologists assign meaning to these anomalies through the use of standard archaeological techniques (i.e., excavations) to establish the human behavior that may have created these patterns. This type of "ground-truthing" is critical in differentiating radar signals that are clearly the result of systematic human behavior as opposed to random noise or other factors.
The actual ground penetrating radar equipment is composed of three parts: 1) a field computer; 2) a control pad; and 3) the radar array itself. The field computer (a laptop) receives, records and displays, in real time, the data transmitted from the control pad-radar array pair. The control pad provides the power, on/off control, settings for the radar array, and transmits data to the field computer. The radar array itself is similar to a metal detector except that the sensor is a one-meter long horizontal bar rather than a disc or ring. The array both sends and receives the electromagnetic pulses that make up the radar images.

\section{Ground-truthing GPR Anomalies: Exploratory Units and Trenches}

Following the conclusion of the GPR survey, the data was to be analyzed for patterned anomalies. The groundtruthing of selected anomalies was to be done using a combination of $50-\mathrm{x}-50$-cm exploratory units (EUs) and/ or 3-4-m long, 50-cm wide exploratory trenches (ETs). These units and trenches were to be hand-excavated only to a depth that was sufficient to reveal grave pit outlines. Since the principal goal of the excavations was to reveal pit outlines, it was decided that the upper $30 \mathrm{~cm}$ of matrix would be removed without the screening of the deposits. Nonetheless, to ensure that significant intact deposits were not missed, sediments were to be inspected for artifacts upon excavation. Excavations were to extend to a depth greater than $30 \mathrm{~cm}$ below surface $(\mathrm{cmbs})$ only if pit outlines were not revealed in the upper $30 \mathrm{~cm}$. In such instances, excavations were to proceed in $10-\mathrm{cm}$ levels and all matrix was to be screened through $1 / 4$-inch hardware cloth.

\section{Machine Scraping}

If the GPR survey and the hand-excavated exploratory units and trenches failed to locate all burial pits present on site, it was proposed that machine grading should be employed in the areas around the known burials and grave markers to identify any outlying burials. The machinery, a common road grader, was to remove 2-3 inches $(5-8 \mathrm{~cm})$ of topsoil during each pass. The project archaeologist was to monitor the soil for any color 
changes or disturbances that may indicate a pit outline. Upon encountering such an outline, hand tools such as shovels and trowels were to be used to define the extent of the pit. The pit or pits were to be photographed and their locations were to be mapped.

Finally, once all graves were identified at the west end of the property, CAR was to stake out an area that was to provide at least a three-foot buffer around the perimeter of the graves. Some type of protective feature would be erected outside of this perimeter to ensure the protection of the graves.

\section{Results of Archival Investigations}

\section{Archival Research}

Given that the goal of the archival research was to compile information on the Perrin Family Gravesite, the research focused on the ownership and history of the cemetery itself. The fate of the original Perrin farm and of the family members not buried in the family plot is only addressed when it provides relevant socialcontextual information concerning the cemetery.

\section{Ownership History}

The 0.7765-acre Perrin Family Gravesite (Bexar County Deed Record [hereafter BCDR] vol. 9940, pg. 1255) was a tiny fraction of a much larger tract of land identified as Survey No. 103 (BCDR vol. 736, pg. 258 and vol. 742, pg. 417). David J. Davis obtained the property's patent from the Republic of Texas on February 5, 1850 (BCDR vol. H. 1, pg. 553). The land went through various owners who did little to alter it until the early 1870 s when Alphonse W. Perrin began to farm the land.

In 1875, Alphonse W. Perrin officially owned 540 acres of land purchased from John W. and Betsy Judson (BCDR vol. 4, pg. 152). After buying the land, Alphonse W. and his wife Nina built a house, started farming, and began to raise a family (Swan 1973). Written sources mentioning the children of Alphonse and Nina are selfcontradictory and conflict with each other concerning birth order, and often do not agree with the dates of birth on the grave markers. What they do all agree on is the number of children and their names. Alphonse and Nina had three sons and five daughters. In alphabetical order these were Alphonse Thomas, Bertha, Frances (Fanny), George, Jean (Jennie), Martha (Mattie), Raymond, and Ruth (BCDR vol. 714, pg. 375 and vol. 742, pgs. 417418; Swan 1973). According to a 1923 letter by M.C. Judson, Bertha and Jennie never married (Swan 1973). Frances (Fanny) married Francis A. McClure, George married Viola (no maiden name given), Martha married Moses C. Judson, and Ruth married William Conry. After being widowed, Ruth later married G.B. Cox (BCDR vol. 736, pg. 358 and vol. 4289, pg. 172; Swan 1973).

After Alphonse W. Perrin's death in 1922, the Warranty Deeds of 1923 divided up the land, haying equipment, and other properties among the family (BCDR vol. 736, pg. 358 and vol. 742, pg. 417). Grantors to the deed were Jennie M. Perrin, Bertha Josephine Perrin, Ruth N. Conry, Moses C. Judson, Mattie C. Judson, Frances C. McClure and Francis A. McClure (BCDR vol. 736, pg. 358).

In 1930 (filed in 1931) and again in 1955, small rightof-ways along the eastern edge of the cemetery were sold by the heirs of Alphonse W. and Nina to Bexar County for the widening of Perrin-Beitel Road (BCDR vol. 1231, pg. 233; BCDR vol. 3717, pg. 430). The cemetery is in the western portion of the plot and was not impacted by these sell-offs. After the last Perrin family member was buried in the cemetery in 1963, the land passed through a series of owners and a tax foreclosure sale. In 2002 the current owners, Harry S. Affleck, Jr. and Ethel Affleck Johnson, purchased the plot from Jui-Yang Chen (BCDR vol. 9440 , pg. 1255).

\section{Burial History}

Only the Perrin family is known to have made use of this plot of land as a cemetery. Their choice in headstone design was not flashy, based on simple clean lines, and fairly typical of modern markers. The headstones are rectangular, light gray granite blocks lying horizontally with one smooth, polished surface angled upwards and bearing the inscription. Side surfaces are left rough to contrast with the polished inscription surface. Those interred in the cemetery are nine members of the Perrin family and one individual of unconfirmed relationship to the family. Table 1 lists the interred, the relevant dates, and the epitaphs that appear on each headstone. Closeup photographs of the individual headstones are presented in Appendix A. The physical arrangement of 
Table 1. Grave Makers and Epitaphs

\begin{tabular}{|l|l|}
\hline \multicolumn{1}{|c|}{ Name } & \multicolumn{1}{c|}{ Dates and Epitaph } \\
\hline Alphonse Thomas Perrin & Sept 14, 1871-Sept 28, 1871 "Of Such is the Kingdom of Heaven" \\
\hline Jean Carr & $\begin{array}{l}\text { In Memory of Jean, wife of T.K. Carr, Born in Ireland Feb 28, 1809, Died } \\
\text { Nov 17, 1891 "Blessed are the Dead which Die in the Lord" }\end{array}$ \\
\hline Raymond E. Perrin & $\begin{array}{l}\text { Aug 25, 1874-May 23, 1912 "Who Patient Bears His Cross Below He } \\
\text { Follows in His Train" }\end{array}$ \\
\hline Nina Carr [Perrin] & $\begin{array}{l}\text { Nina Carr wife of A.W. Perrin, Born in Ireland May 18, 1843- June 23, } \\
\mathbf{1 9 1 2} \text { "He Giveth His Beloved Sleep" }\end{array}$ \\
\hline Juan Arispe & Fallecio Nov 21, 1916 A La Edad De 58 Años D.E.P. \\
\hline Alphonse W. Perrin & $\begin{array}{l}\text { Feb 23 1848-Oct 18 1922 "To do Justly, To Love Mercy and to Walk } \\
\text { Humbly with Thy God" }\end{array}$ \\
\hline Jennie M. Perrin & Jan 31, 1873-May 28, 1950 "His Name Shall Be On Their Foreheads" \\
\hline Bertha J. Perrin & Dec 12 1884-Dec 27, 1958 "He Giveth His Beloved Sleep" \\
\hline \multicolumn{1}{|c|}{ McClure } & $\begin{array}{l}\text { Frances P. [Fanny]: 1880-1959 and Francis A.: 1884-1963 } \\
\text { "The Lord is Our Shepard, We Shall Not Want" }\end{array}$ \\
\hline
\end{tabular}

the headstones from south to north is as follows: A.W. Perrin, A.T. Perrin, Nina Carr, Bertha Perrin, Jean Carr, Jennie Perrin, Raymond Perrin, F.A. McClure and F.P. McClure. The headstone of Juan Arispe now sits between Jennie and Raymond but this is not his burial site as his stone has been frequently moved.

The first use of this small plot of land as a gravesite was unexpected and unfortunate. The earliest grave marker is of Alphonse and Nina's first-born son, Alphonse Thomas Perrin, born 14 September 1871, died 28 September 1871 . As this date indicates, the Perrin family was living on the land prior to receiving the deed in 1875 . The $27^{\text {th }}$ of January 1875 recorded in the Bexar County Courthouse Deed Records is likely when they made the final payment (BCDR vol. 4, pg. 152).

The second interment was Jean Carr, born 1809, died 1891. Jean Carr is most likely the mother of Nina Carr Perrin, since both were born in Ireland and Jean was 35 years older than Nina. It is also probable that Jean Perrin (more often referred to, and buried as, Jennie) was named after her grandmother Jean Carr. Raymond Perrin, born
1874, was next to be buried in May 1912. His mother, Nina Carr Perrin, died and was buried only a month later.

The Juan Arispe headstone has the following inscription “fallecio 1916 A La Edad De 58 años D.E.P.” This would place his birth in 1858. It should be noted that fallecio, meaning died or deceased, has been misread as Arispe's last name, Fallerico, in several newspaper article clippings (dates of print missing) and other publications (Benoit n.d.; San Antonio Genealogical and Historical Society 1999).

Juan Arispe's headstone is unusual for a number of reasons. It is the only marker that is not a Perrin family member by blood or marriage. It is documented that the Perrins employed immigrant workers from either Latin America or Mexico (Swan 1973). Juan may have been a well-liked farmhand that was interred in the family cemetery (Benoit n.d.). Aside from the inscription being in Spanish, the design of the Arispe headstone also differs from the Perrin headstones. The stone is of sandstone and is made in the form of a pillar with well-dressed (smooth) sides. A separate bevel-sided piece sits on top 
of the pillar and a hole at the top of this piece suggests that an additional, now missing, piece of ornamentation complemented the design. The current location in line with the other headstones is a recent move. Two prior locations of the Juan Arispe stone have been noted and neither can be the original gravesite (see Fieldwork and Results of Investigations).

In 1922, a decade after the death of his wife Nina, Alphonse W. Perrin was laid to rest. Twenty-eight years later, in 1950, Jennie Perrin was interred in the cemetery followed by Bertha Perrin in 1958. The most recent burials are of Frances P. (Fanny Perrin) McClure in 1959 and her husband Francis A. McClure in 1963. Frances, whose middle name was Caroline (BCDR vol. 714, pg. 375 ) is listed on the grave marker as Frances P. McClure. The "P" likely refers to Perrin, Fanny's maiden name. She was also referred to as Frances P. McClure in a 1955 deed record (BCDR vol. 3717, pg. 340). As of February 2003, the McClures are the last to be laid to rest in the Perrin Family Gravesite.

In a 1973 paper done by former Baylor University student Tim Swan, a photo of the cemetery is included. The image is unclear but shows gravestones overgrown with vegetation. The photograph's caption lists the dead as:

"Alphonse, Alphonse Thomas... Nina, Bertha, Jenny, Ruth, Raymond and Francis Perrin McClure and Frances McClure."

The listing of Ruth in the cemetery is contrary to grave marker indications. This could lead to speculation of a missing marker, however, this photo caption is filled with inaccuracies leading the author to infer the inclusion of Ruth's name to be an inaccuracy as well. First and most noticeably, it omits Jean Carr who has been in the cemetery since 1891. In the caption, Jennie's name is misspelled with a "y" and the McClures names are confused. Francis Perrin McClure is meant to be Fanny, while Frances is to indicate her husband. However, the deed records of 1923, 1927, 1930, and 1955 (BCDR vol. 714, pg. 375; vol. 939, pg. 521; vol. 1169, pg. 80; vol. 3717 , pg. 430) and the headstones themselves indicate Francis A. McClure is the husband's name and Frances P. is Fanny's name. These errors would suggest that the source placing Ruth Cox (A.K.A. Ruth Perrin, Ruth Conry) in the cemetery is mistaken.

\section{Fieldwork and Results of Investigations}

Initially, CAR staff considered the entire 34,480-squarefoot property as part of the project area within which burials associated with the Perrin Family Gravesite were likely to be found. However, an inspection of the recently completed geotechnical engineering study of the property (Arias and Kezar, Inc. 2001) indicates, that while the western 100 feet of the property is overlain by approximately 3.5 feet of clay with some sand (see Figure 2 for boring locations and Appendix B for boring logs), the eastern 330 feet only contains some 6-10 inches of clay (see Appendix B). The clay is underlain by Cretaceous marine deposits and marlstone, throughout the eastern two-thirds of the project area. Figures 2 and B-1 through B-4 are reproduced from the Arias and Kezar (2001) geotechnical report.

Given the thin topsoil present in the eastern two-thirds of the property, it is unlikely that graves would have been excavated in such shallow soils. In addition, it is very likely that any shallowly buried caskets would have been identified as the 1.0-1.5 feet of topsoil was removed from this area. No graves or related features were observed by the construction crews during the removal of topsoil and it is likely that none existed in the shallow soils.

Based on the geotechnical information, the approximately 330-foot eastern portion of the property was excluded from further consideration. This was due to the lack of sufficient deposits which, would allow for proper burials and the fact that such shallow burials would already have been identified during the removal of topsoil from the area. Instead, archaeological efforts concentrated on the western one-third, or approximately 100 -foot long section of the property where the headstones are currently located (Figure 3 ).

\section{Ground Penetrating Radar (GPR) Survey Results}

GPR sweeps followed transects set up at one-meter intervals. Transects were oriented south to north across the property and perpendicular to the assumed arrangement of caskets associated with the headstones. Figure 4 presents the results of the GPR survey. Blues 
and greens represent lower values (negative readings) while areas depicted in yellow and orange represent higher values and red indicates the highest positive readings indicative of subsurface disturbances. The beginning of each radar sweep is marked by dark blue and blue values (Figure 4). Although the GPR did not highlight any specific burials, it seems to show an area of higher intensity in the vicinity of the graves as indicated by the orange and red intensity levels. In addition, although one of the areas characterized by positive readings is immediately east of the row of headstones, other positive readings are scattered throughout the 8,000 -square-foot area.

\section{Ground-truthing Excavation Results}

Given that the GPR survey resulted in positive readings adjacent to as well as away from the headstones, it was necessary to investigate the nature of at least some of these positive hits. To accomplish this, one exploratory unit (EU1) was placed 5.5 meters north of grid marker 11 (Figure $3)$. This $50-\mathrm{x}-50-\mathrm{cm}$ unit was excavated to a depth of $50 \mathrm{cmbs}$ over a GPR anomaly location (see Figure 4 at $5.5 \mathrm{~m}$ from grid marker 11). Two small pieces of recent clear glass were removed from the surface (not collected) and a few natural limestone gravels were found during excavation. No cultural materials were recovered from EU1

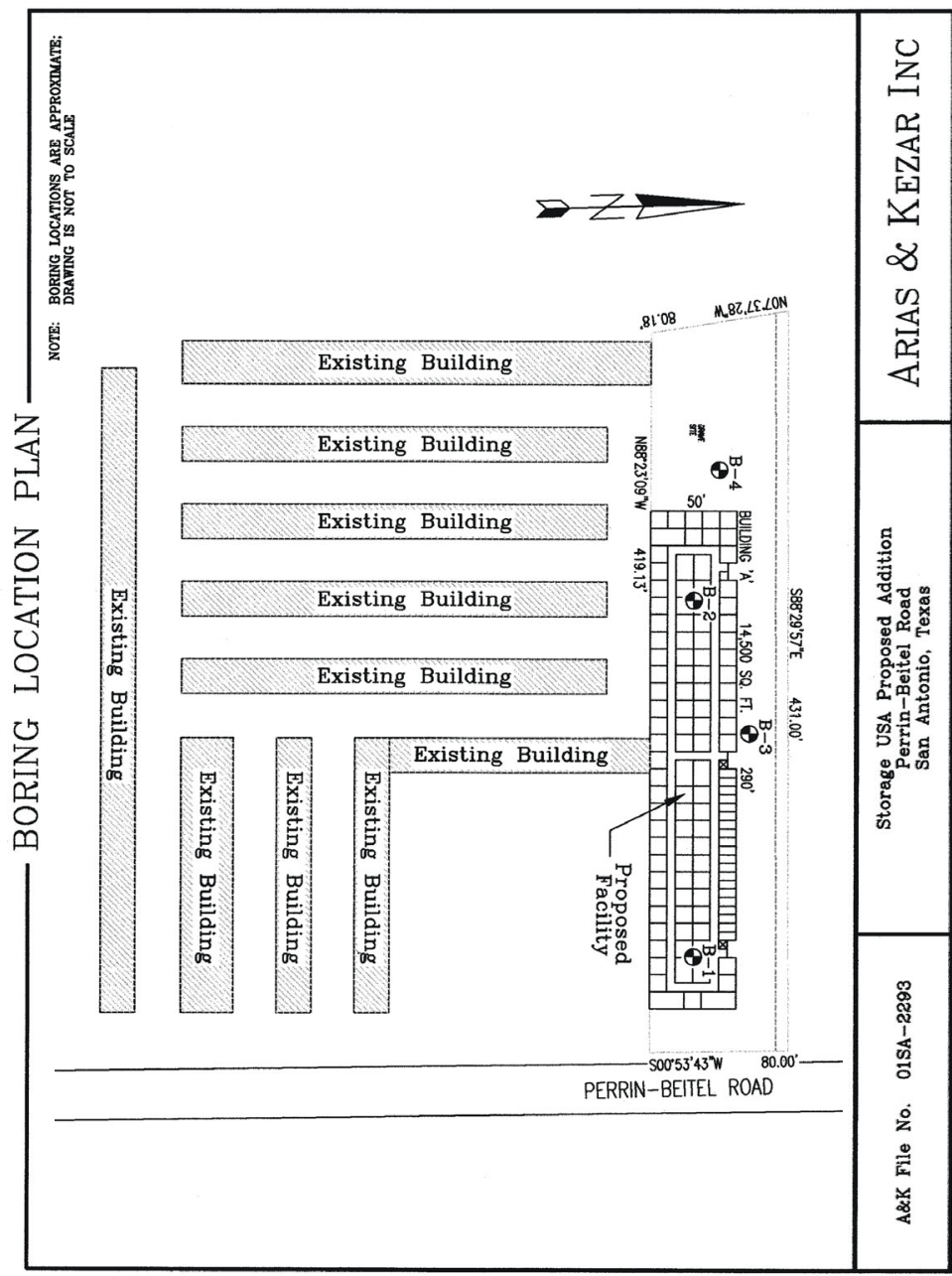

Figure 2. Geotechnical boring location plan. and no soil texture or color changes were noted.

In addition, to verify the presence of graves associated with the headstones, three exploratory trenches (ET1ET3), oriented to magnetic north, were hand-excavated about one meter east of the line of headstones (Figure 3 ). Two of the trenches were three meters long and the third was four meters long, all three were only 50 centimeters wide.

Exploratory Trench 1 (ET1) began one meter north of the McClure grave marker and proceeded south four meters ending just past Raymond Perrin's headstone (see Figure 5). The excavations revealed two burial pit outlines at a depth of between 26 and $30 \mathrm{cmbs}$. The two grave outlines are oriented east-west and appear as black (10YR 2/1) rectangular stains within a lighter colored clayey soil (10YR 3/2). The two burial pits in ET1 are likely Francis and Frances McClure (Figure 5).

Trench 2 (ET2) began one meter south of ET1 and was three meters long. To the west of the location of ET1 are Jean Carr's and Bertha Perrin's markers with Juan Arispe's and Jennie Perrin's markers west of the space between ET1 and ET2 (Figure 5). There were four burial pit outlines visible at $30 \mathrm{cmbs}$. Again, the clayey soil of the burial pits is black (10YR 2/1) but the surrounding soil is a very dark gray (10YR 3/1). In plan view, the burial pits in ET2 are oriented east-west just like those in ET1 (Figure 5). Judging from their position relative to the headstones, these are likely the graves of Raymond Perrin, Jennie Perrin, Jean Carr, and Bertha Perrin. The 


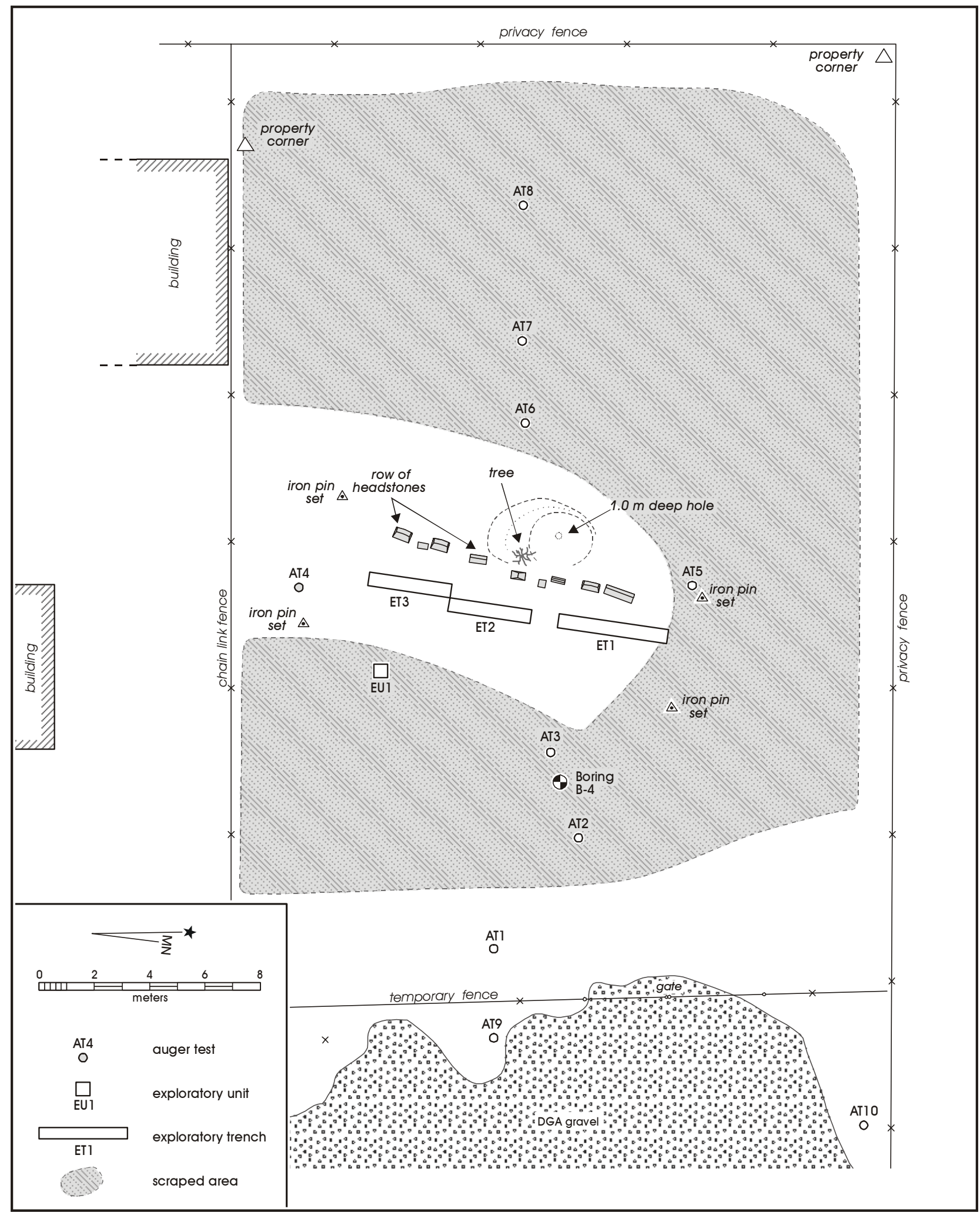

Figure 3. Site map showing locations of all excavations and iron pins. 


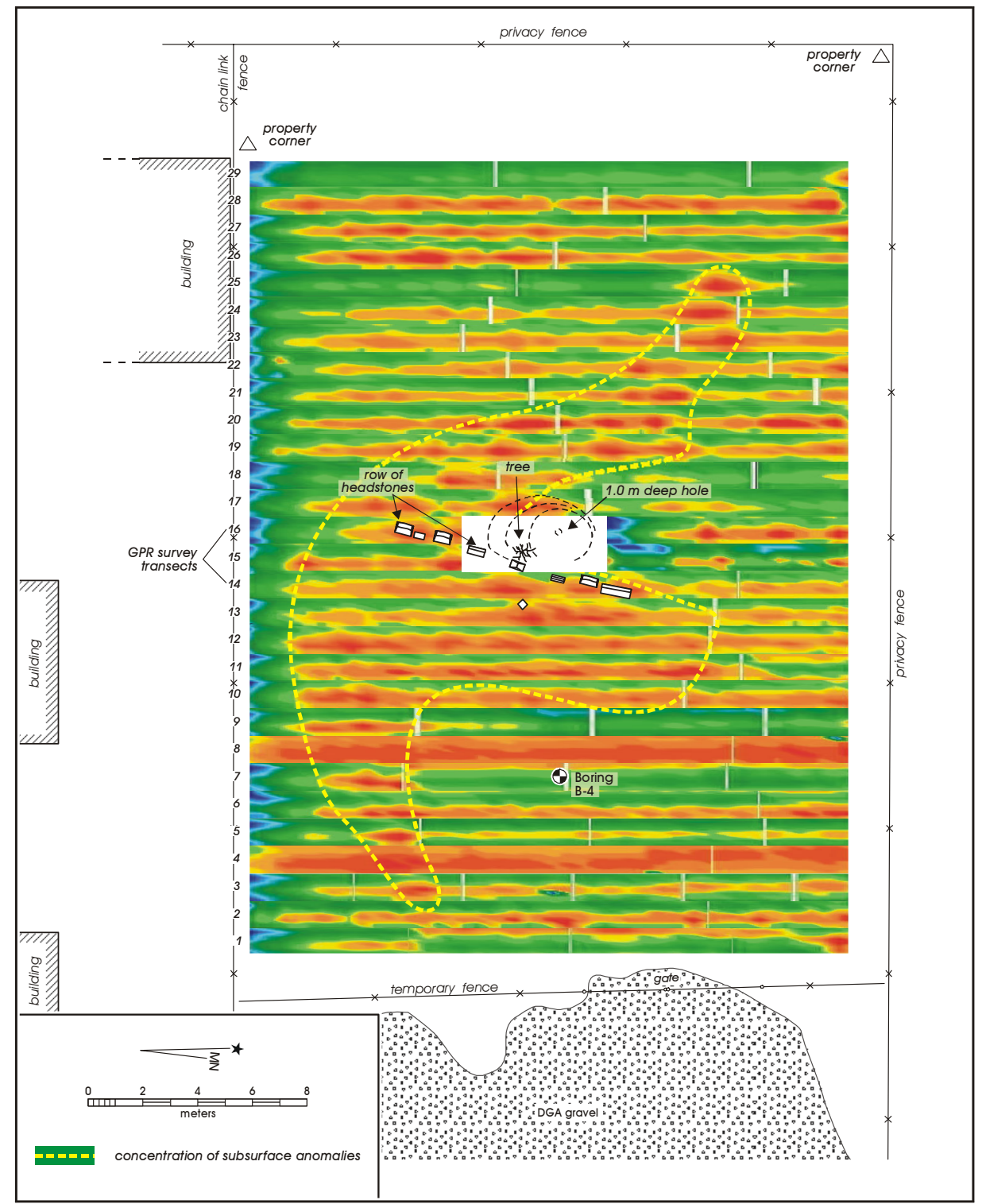

Figure 4. Ground Penetrating Radar (GPR) imaging results.

stones do not line up perfectly and suggest slight movement at some point in time from their original positions.

Exploratory Trench 3 (ET3) was three meters long and placed immediately south of and 50 centimeters offset to the west of ET2 so that its northeast corner adjoins the southeast corner of ET2 (Figures 3 and 5). There were four burial pits noted at $30 \mathrm{cmbs}$ in ET3. As with ET2, the color of the soil in the burial pits is black (10YR $2 / 1$ ) and a close match to the very dark gray (10YR 3/1) of the surrounding soil. The partial southernmost grave outline in ET2 continues in the northernmost portion of ET3 (see Figure 5). The final three east-west oriented grave outlines are close together with the southernmost burial pit extending beyond the southern wall of the trench (Figure 5). It is possible that the southernmost burial may extend as much as a meter south of the southern edge of the exploratory trench. The last three graves are likely those of Nina Carr, Alphonse T. Perrin, and Alphonse W. Perrin. 
Excavations of the test trenches recovered no historic or prehistoric cultural materials. Furthermore, no screening of the matrix was necessary since none of the trenches extended more than $30 \mathrm{cmbs}$.

The dark stains of the burial pits do not align perfectly with the headstones (Figure 5). This suggests that the headstones have been moved from their original locations and this information is consistent with anecdotal information. Additionally, nine burial pit outlines were found corresponding to the nine Perrin-Carr-McClure headstones. This left only Juan Arispe's grave location unaccounted for.

At the time of the fieldwork, Juan Arispe's marker was located between the headstones of Jennie Perrin and Jean Carr. This is not where he is buried. Two earlier locations of Juan Arispe's marker are known (Figure 5). The location previous to its current one is approximately 50 $\mathrm{cm}$ south of the north wall of ET2. Before excavations disturbed this spot, a square patch of bare dirt marked its old location in the green grass surrounding the graves. An even earlier location is in front of Alphonse T. Perrin's marker as indicated by a square subsidence in the ground now grown over with grass. As with the bare patch, both are the same dimensions as the base of Juan Arispe's

Table 2. Auger Test Locations and Depth to Bedrock

\begin{tabular}{|c|c|c|}
\hline Auger Test \# & $\begin{array}{c}\text { Distance and Direction } \\
\text { from Jean Carr's Grave }\end{array}$ & $\begin{array}{c}\text { Depth to Bedrock } \\
\text { (cmbs) }\end{array}$ \\
\hline $\mathbf{1}$ & 13 meters East & 82 \\
\hline $\mathbf{2}$ & 9 meters East & 97 \\
\hline $\mathbf{3}$ & 6 meters East & 101 \\
\hline $\mathbf{4}$ & 8 meters South & 140 \\
\hline $\mathbf{5}$ & 6 meters North & 70 \\
\hline $\mathbf{6}$ & 6 meters West & 40 \\
\hline $\mathbf{7}$ & 9 meters West & 34 \\
\hline $\mathbf{8}$ & 14 meters West & 57 \\
\hline $\mathbf{9}$ & 16 meters East & 42 \\
\hline $\mathbf{1 0}$ & 23 meters Northeast & 56 \\
\hline
\end{tabular}

stone. Conversation with the manager of the storage facility to the south of the cemetery revealed that she has see Juan Arispe's stone in numerous locations over the past few years. This means that almost certainly, none of the graves noted in the exploratory trenches represented Juan Arispe's grave. Hand-excavated trenches found only nine burials, therefore, the tenth grave, the one belonging to the Juan Arispe headstone, was still missing.

\section{Auger Test Results}

To precisely identify areas with thick soils that may be more suitable for deep graves, the depth of the bedrock substrate across the western 8,000-square-foot area was determined using auger tests. Ten auger tests (AT) were hand-dug within the designated area. Their locations are shown in Figure 3 and the depth of the substrate in each is listed in Table 2. Distance from the cemetery to the auger tests is measured in proximity to Jean Carr's gravestone, as it is centrally located.

As a general rule, the depth to bedrock was greater closer to the graves and decreased away from the graves. The deepest tests were AT 2,3, and 4. The results of the auger tests indicate that the location of the cluster of headstones represents a relatively small pocket of deep soils that extends to at least three feet below surface. Areas surrounding this approximately 30 by 25 foot area are covered by soils that are less than three feet in thickness.

This finding indicates that it is likely that the Perrin family members used some method (i.e., probing) to identify the location and size of this pocket of deeper soils within this tract of land. Similarly, and not surprisingly, the finding also suggests that the graves were deliberately placed in the area of the property that had the deepest soils and the best potential to allow the adequate burial of the caskets. 


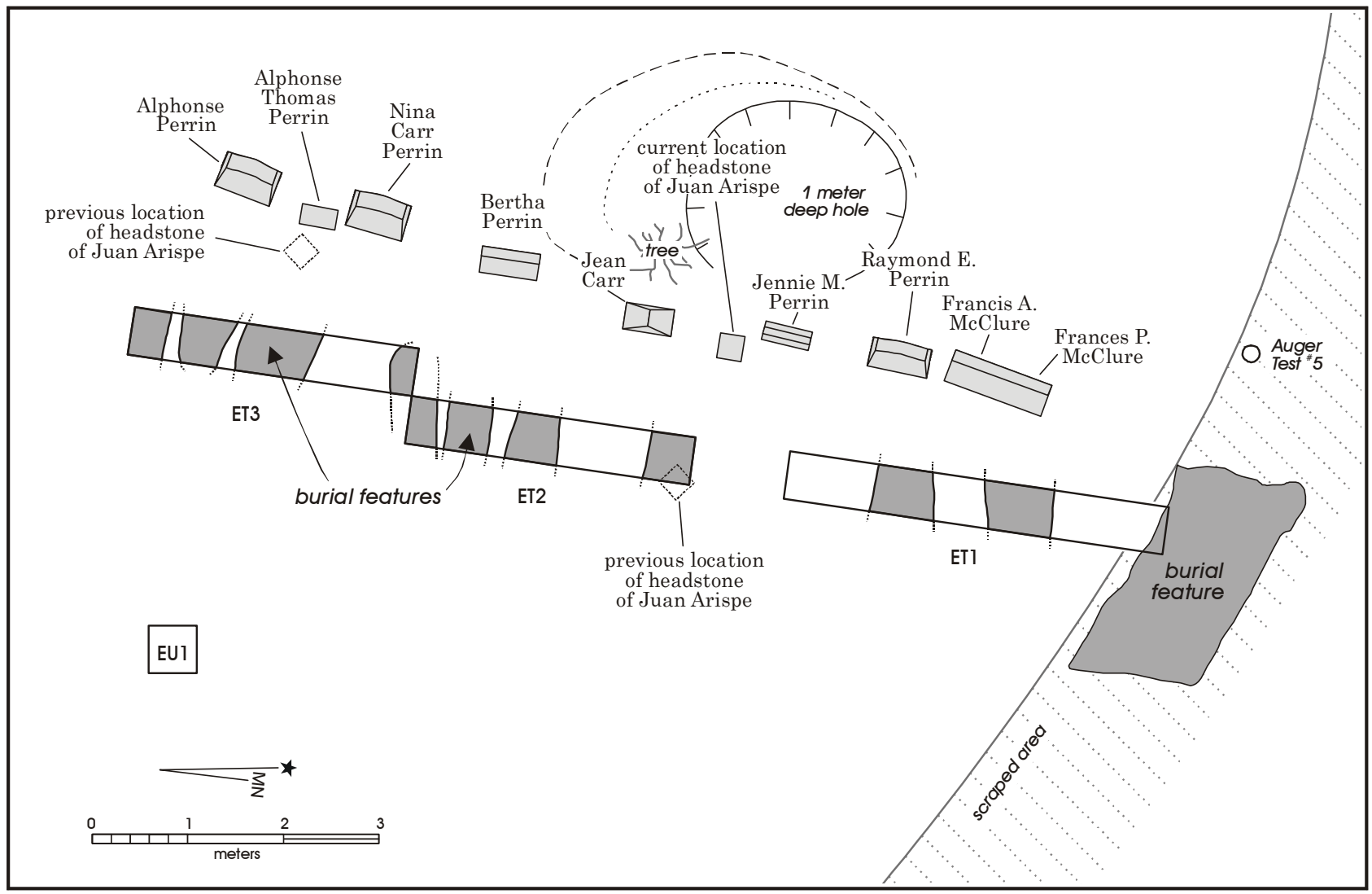

Figure 5. Burial feature locations.

\section{Machine Scraping Results}

The hand-excavated trenches only located nine of the ten burials known to be in the Perrin Family Gravesite. To locate the tenth burial, likely Juan Arispe, machine scraping was conducted to the north, east and west of the known burials (Figures 3, 5, and 6). Following the methods detailed earlier, the scraping removed approximately $50 \mathrm{~cm}$ of topsoil east of the graves, $30 \mathrm{~cm}$ of soil west of the graves, and $30-40 \mathrm{~cm}$ of soil north of the headstones. While no indications of additional graves were noted east or west of the existing headstones, a tenth grave was identified approximately 1.5 meters to the north of the McClure gravestone (Figure 5). The fill of the burial pit is a brown (10YR 4/3) clay loam with caliche. While the fill in the graves identified in ET1, ET2, and ET3 is dark gray clay, the tenth grave is filled with brown marlstone that underlies the black clay. This indicates that the tenth grave was dug into the marlstone substrate and this matrix was then used to cover the casket. This pattern also suggests that the other nine graves on the property were not dug deep enough to contact the brown marlstone substrate.

On March 12, 2003, B. Moses of CAR visited the site and surveyed in four iron pins marking the corners of the area to be protected from construction-related disturbances (see Figure 3). Subsequently, surveyors from Pape-Dawson Engineers, Inc. conducted a formal survey of the small tract encompassing the Perrin Family Gravesite. This survey document is provided in its entirety in Appendix C.

\section{Conclusions and Recommendations}

\section{Archival Research}

Archival research was able to confirm that ten individuals were buried in the Perrin Family Gravesite. However, research did not locate any archival information regarding the exact location of each burial or a precise list of those 


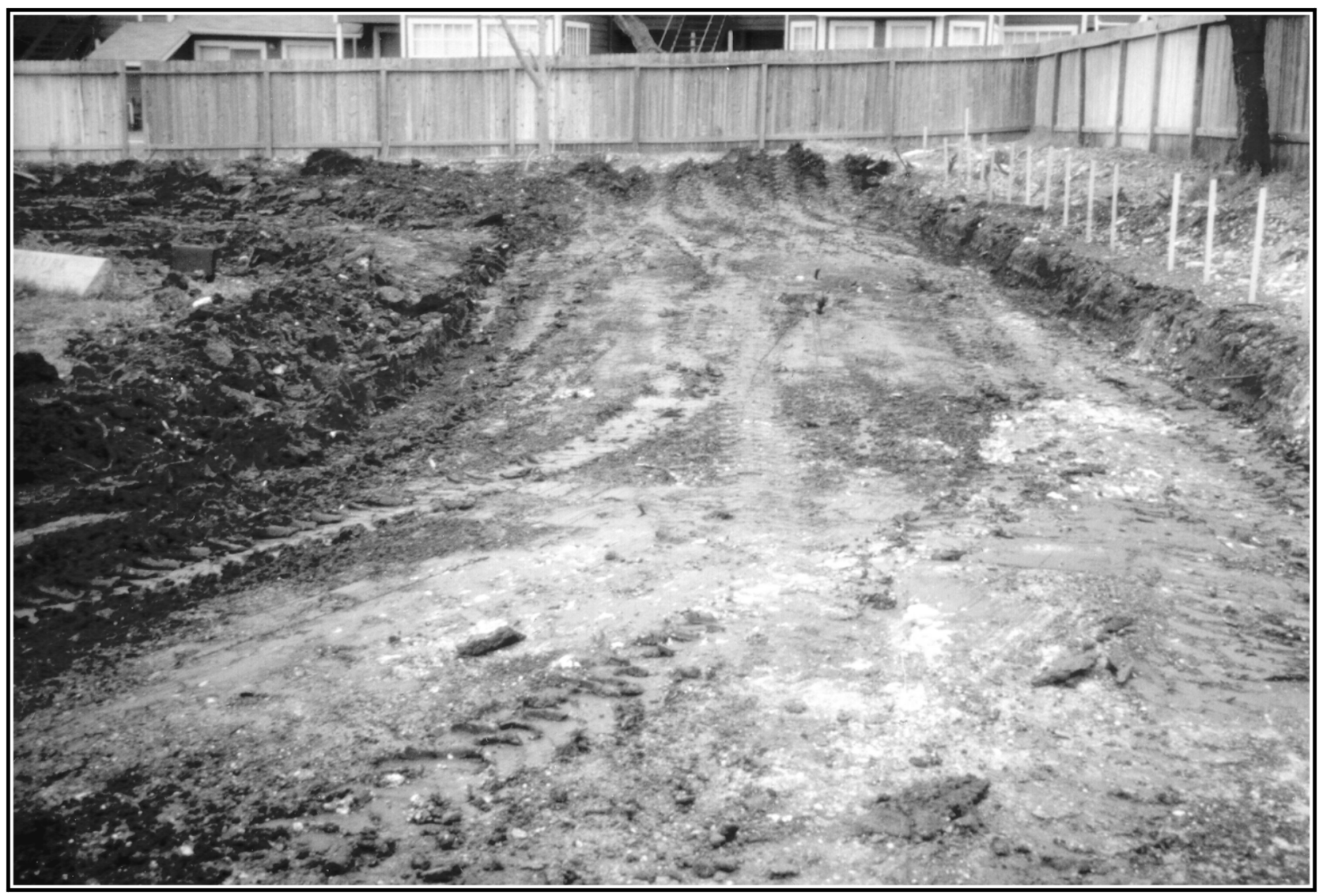

Figure 6. Area of machine scrape looking west.

buried. No formal maps have ever been made or detailed descriptions ever given of the gravesite. The best evidence for the number, identity and location of persons buried in the Perrin family graves has proven to be the grave markers themselves and the results of excavations.

\section{Fieldwork}

The GPR scans were somewhat unclear but did reveal a general area of higher intensity signals within the 8,000square-foot area. An exploratory unit and three handexcavated trenches, in combination with machine scraping, revealed ten burial pit outlines in the general location of the ten headstones. Machine scraping over the remainder of the project area uncovered no additional burials. While the investigations suggest that the headstones are not likely in their original locations, the excavations have accounted for all ten individuals known to be buried in the Perrin Family Gravesite.

\section{Recommendations}

As archival research does not contradict the results of field investigations it is believed that there is a high probability the ten burials located near the ten grave markers represent all of the human interments in the Perrin Family Gravesite at 9501/9505 Perrin-Beitel Road, San Antonio. It is recommended that the landowner proceed with plans to construct some form of protective feature to encompass all ten graves identified during the archaeological investigations. This feature should include not just the immediate graves themselves but the entire gravesite, as it is depicted in Appendix C, in order to provide a buffer around the entire circumference of the graves. 


\section{References Cited}

Arias \& Kezar, Inc.

2001 Geotechnical Engineering Study, Storage USA Proposed Addition, San Antonio, Texas. Prepared for Artistic Builders, Inc. Manuscript on file at the Center for Archaeological Research, The University of Texas at San Antonio.

Benoit, P.

n.d. "Cemetery Sleuth Trying to Save Once-lost Graves,” Express News. pp. 1-G, 3-G.

San Antonio Genealogical and Historical Society Members

1999 Cemeteries of Bexar County Texas. San Antonio Genealogical and historical Society, Texas.

Swan, T.

1973 Hope Farm-A Century of Change. Unpublished Geology 101 Paper, Baylor University, Texas. 
Appendix A

\section{Headstone Photographs}




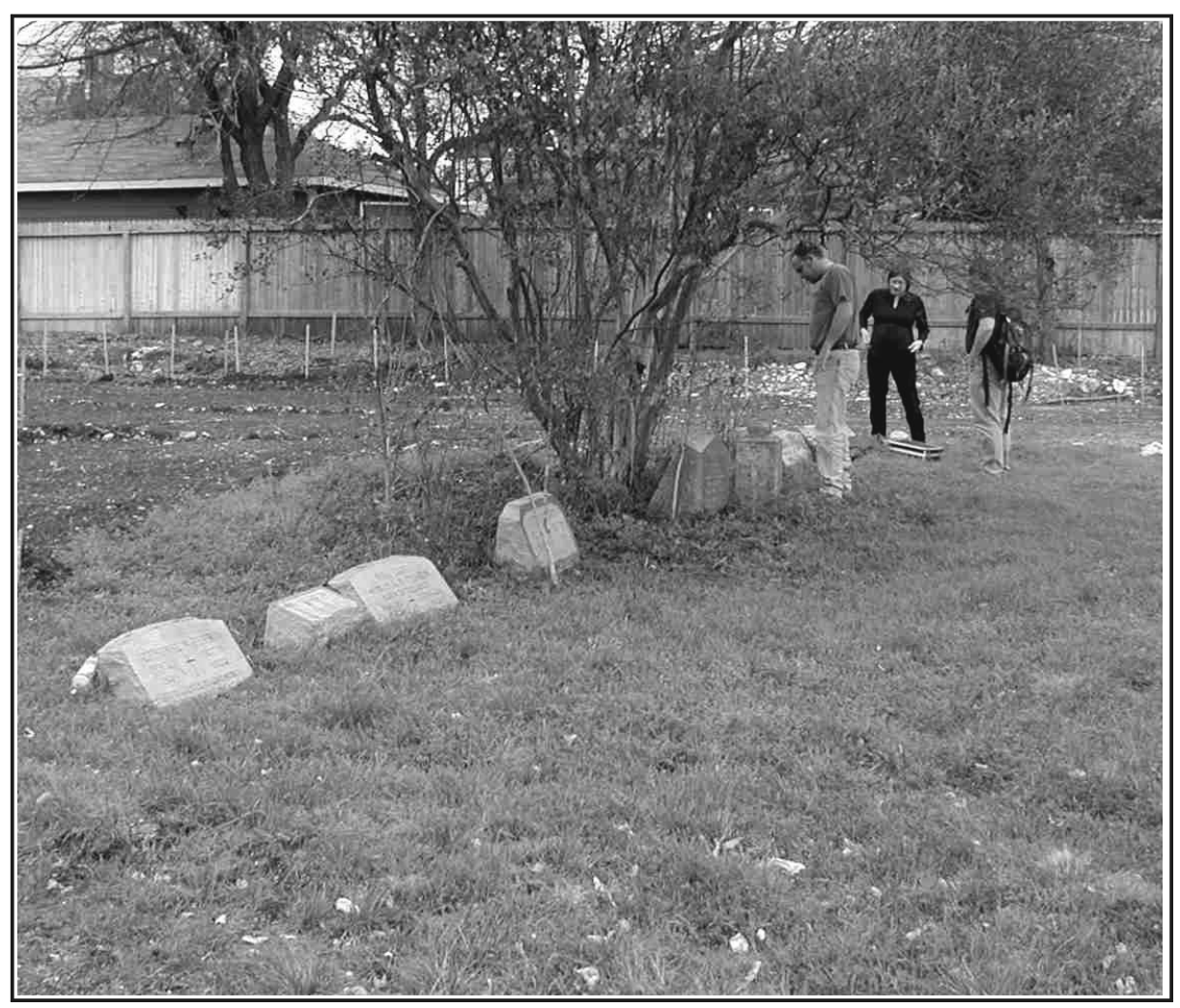

Figure A-1. Overview of headstones in Perrin Family Gravesite.

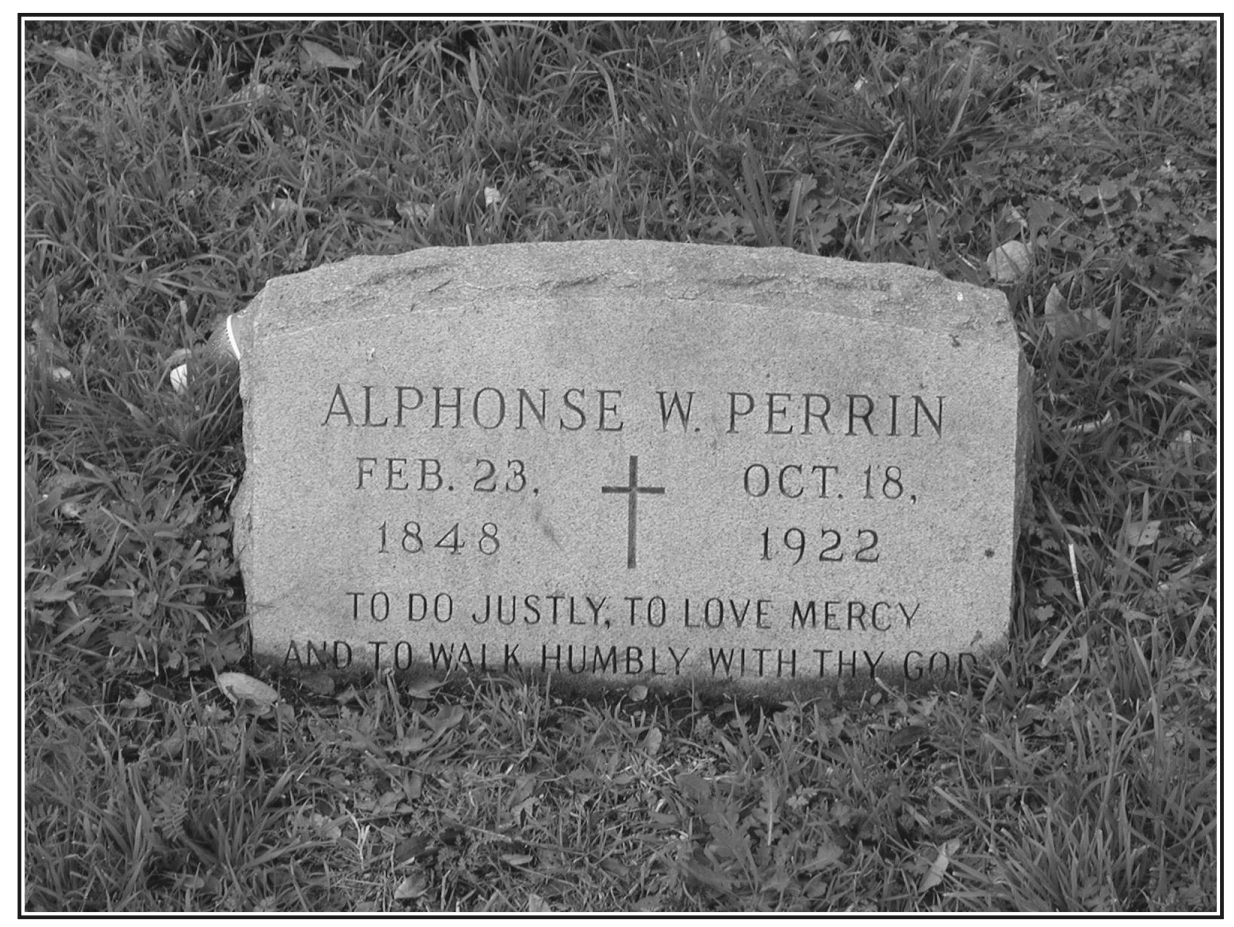

Figure A-2. The Alphonse W. Perrin headstone. 


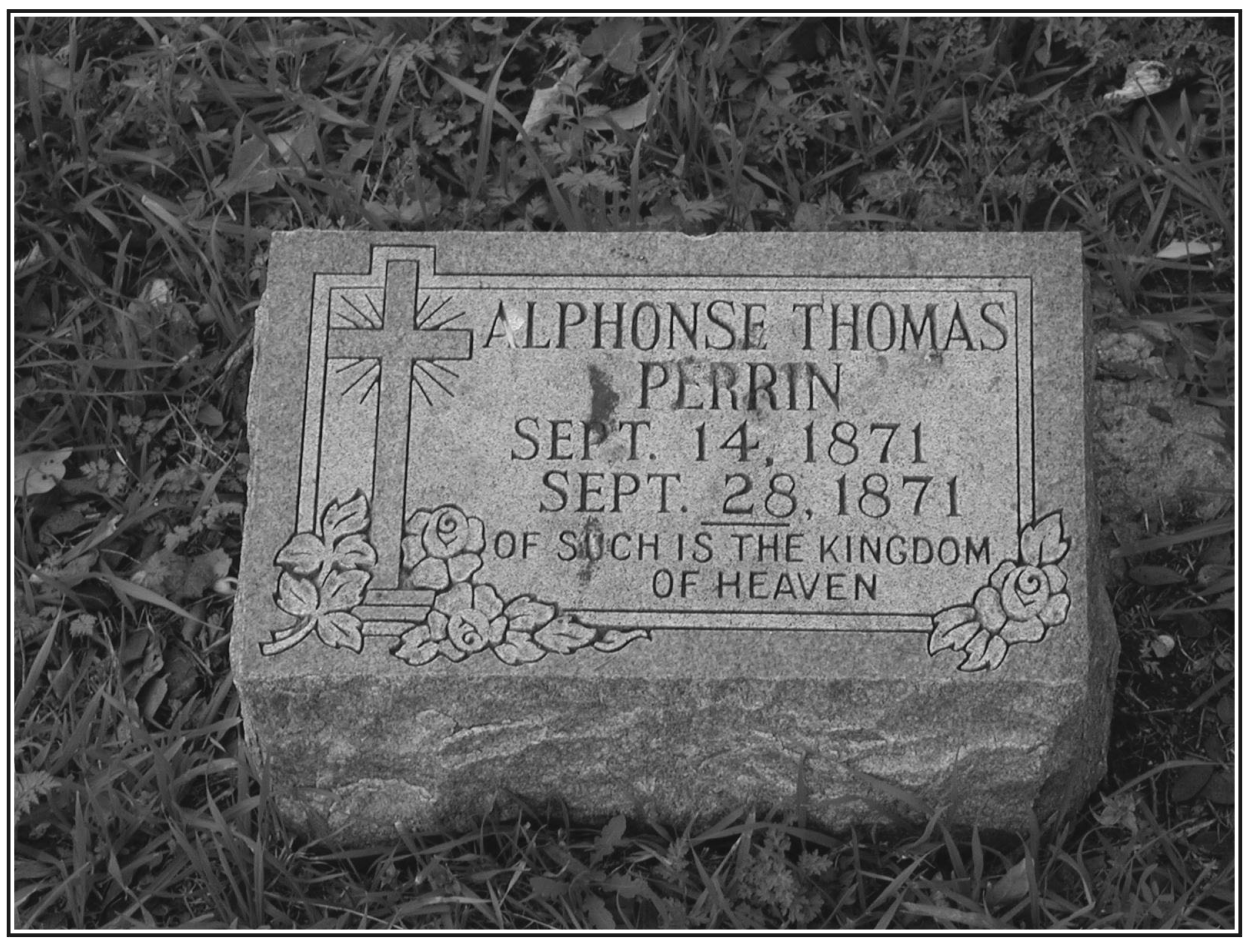

Figure A-3. The Alphonse Thomas Perrin headstone.

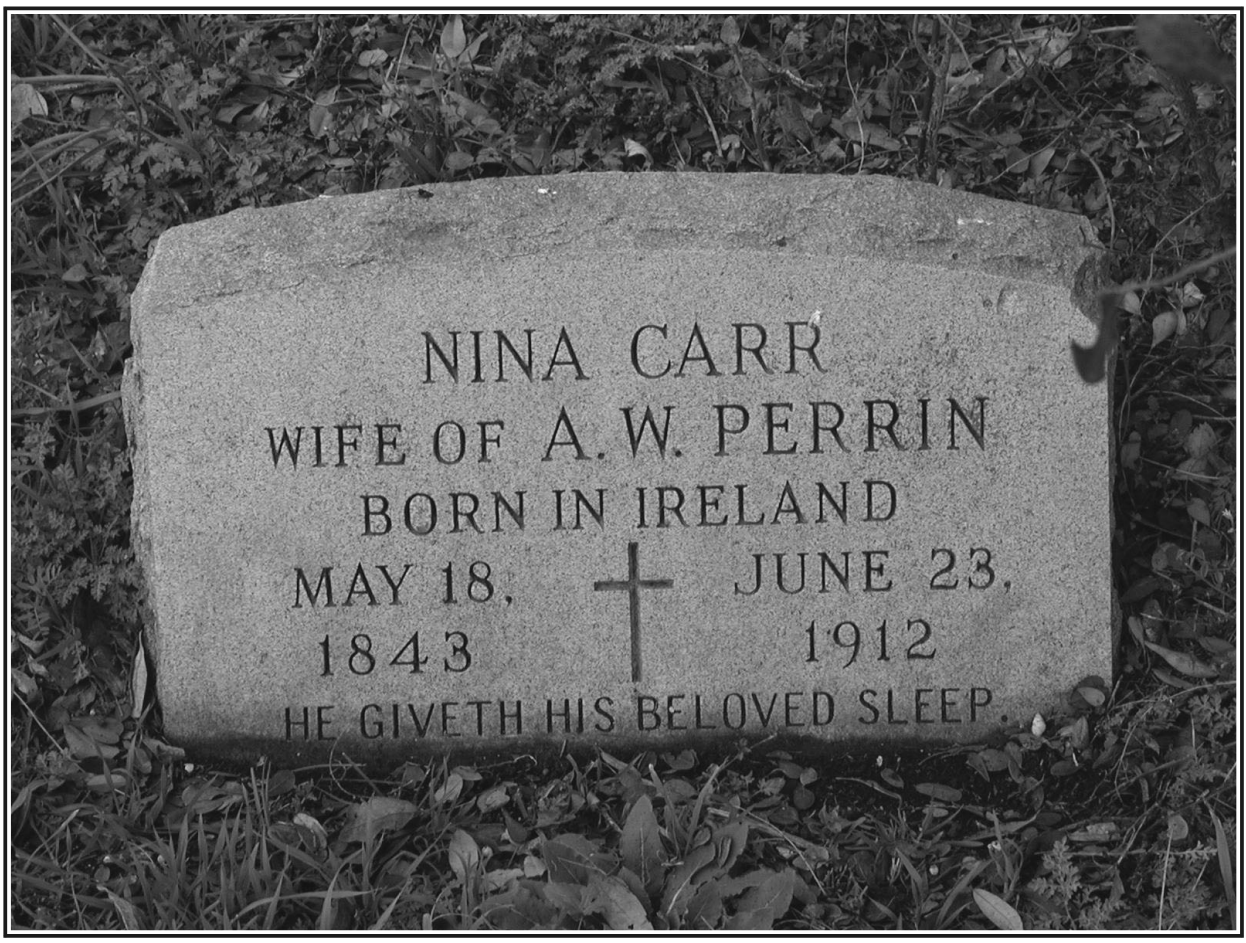

Figure A-4. The Nina Carr headstone. 


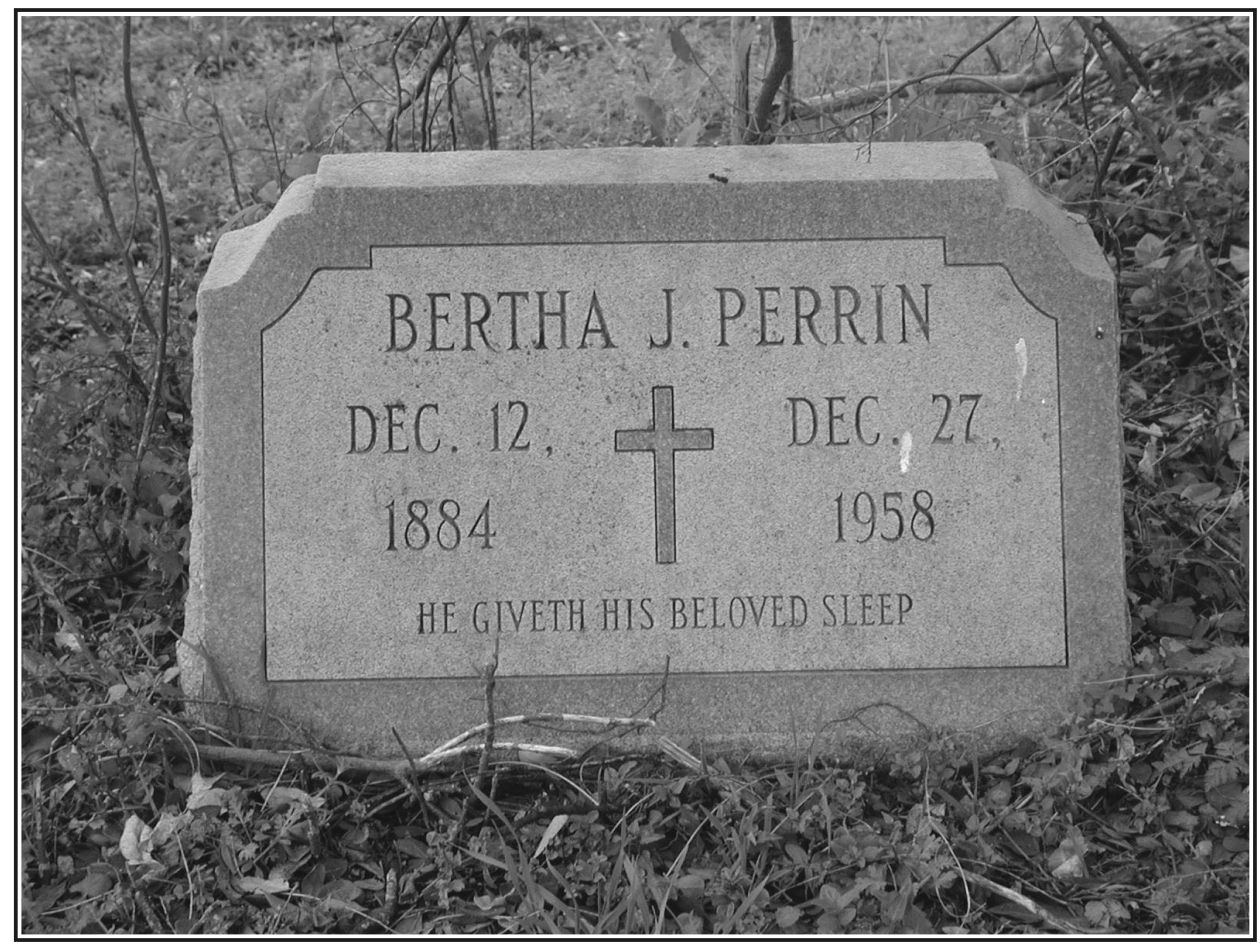

Figure A-5. The Bertha J. Perrin headstone.

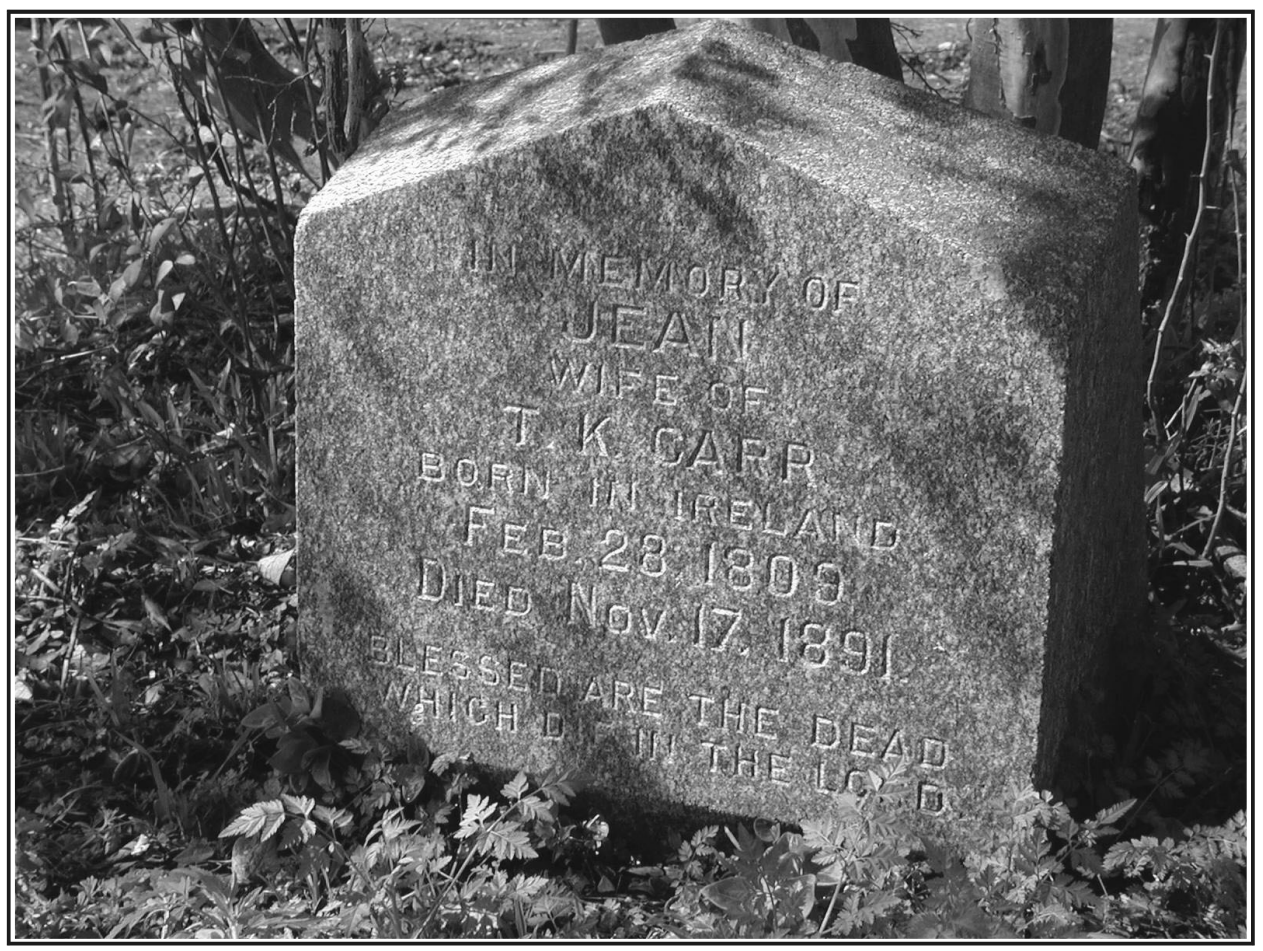

Figure A-6. The Jean Carr headstone. 


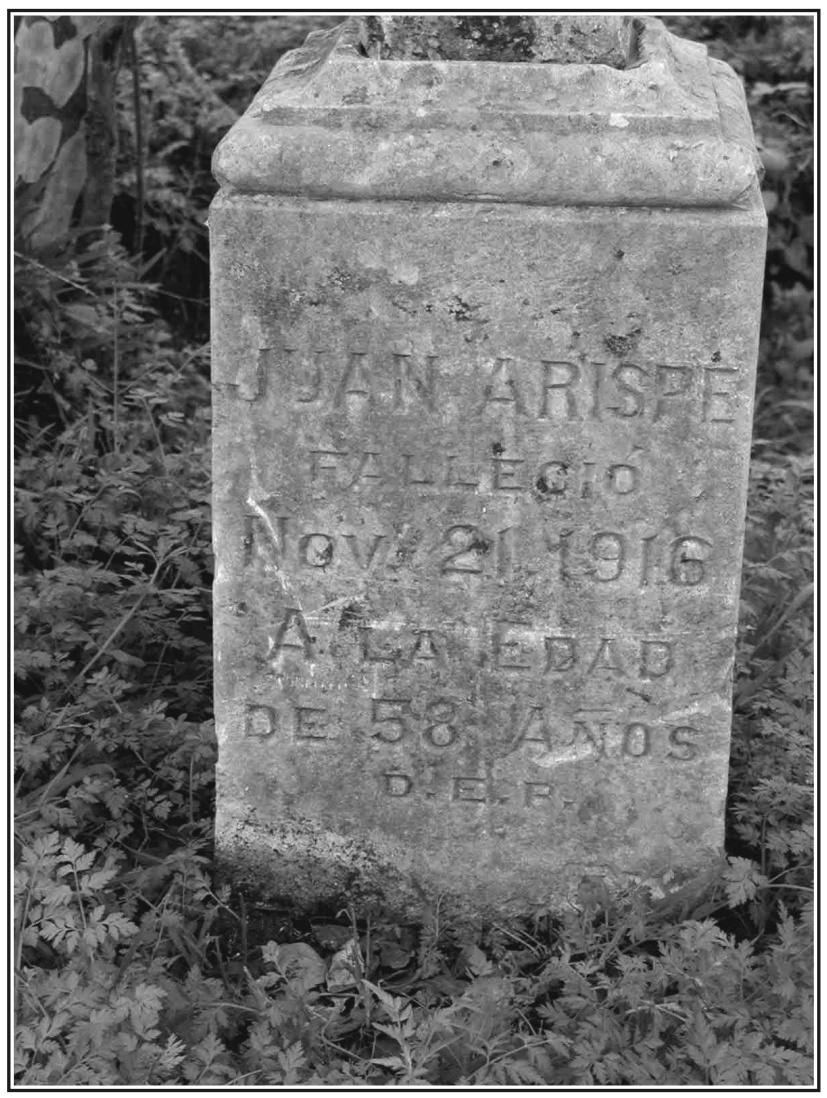

Figure A-7. The Juan Arispe headstone.

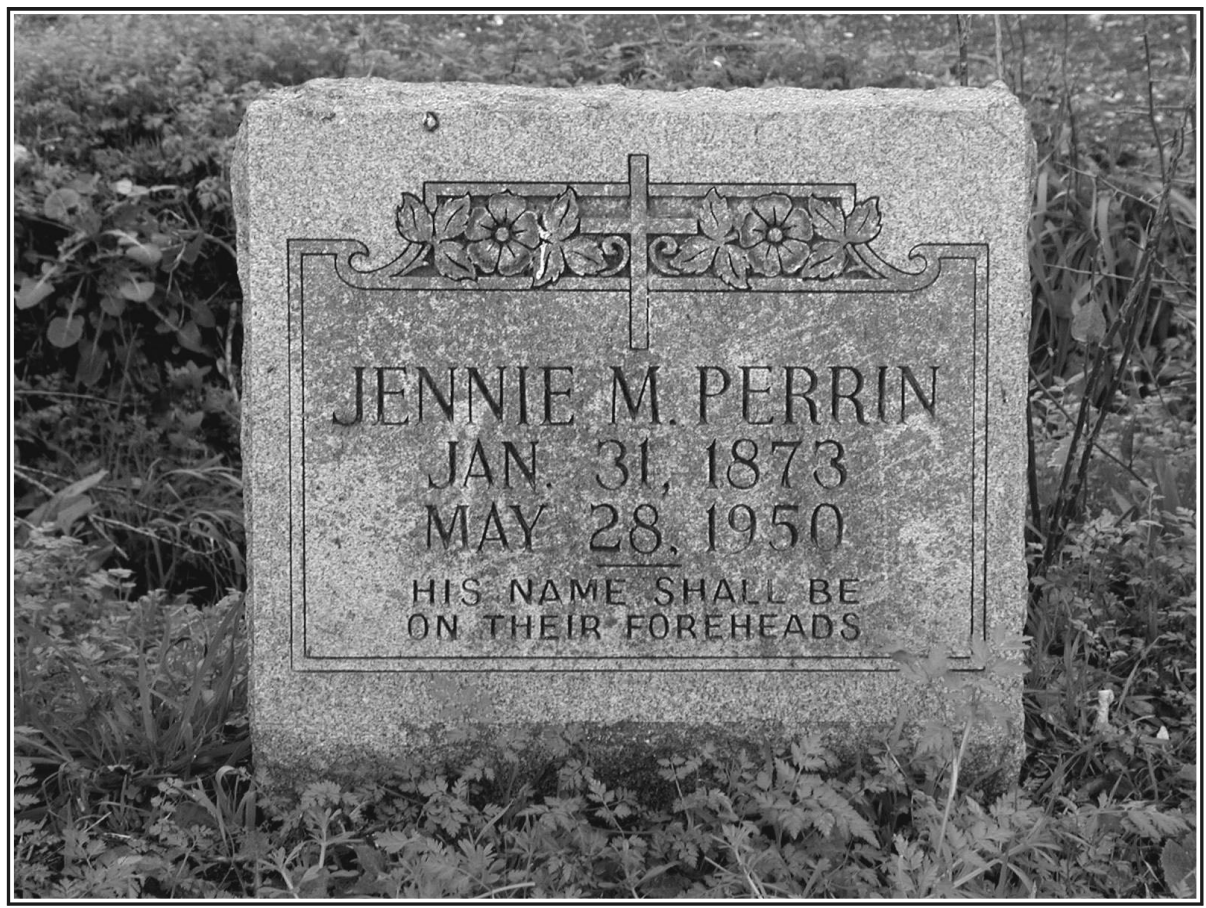

Figure A-8. The Jennie M. Perrin headstone. 


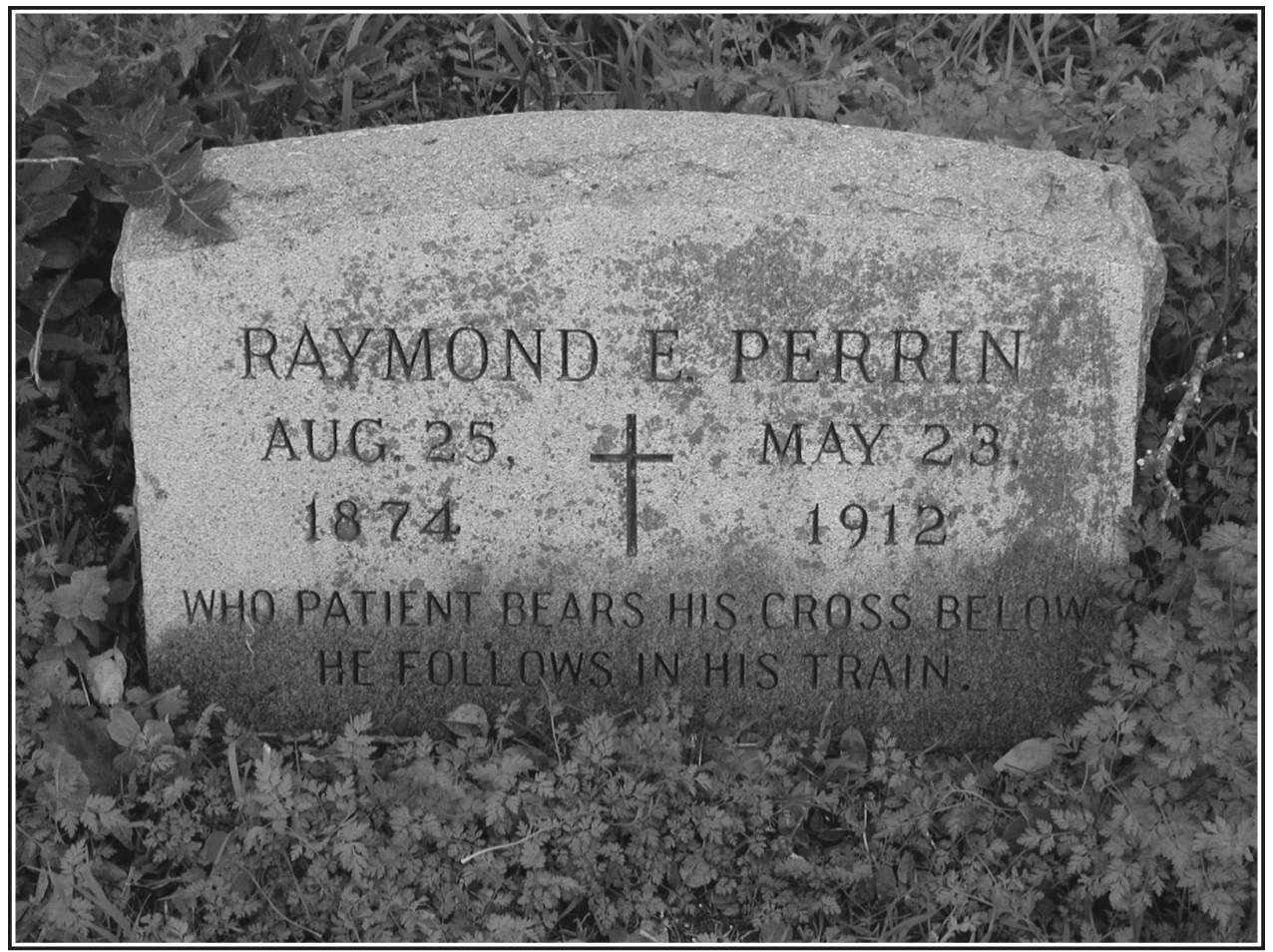

Figure A-9. The Raymond E. Perrin headstone.

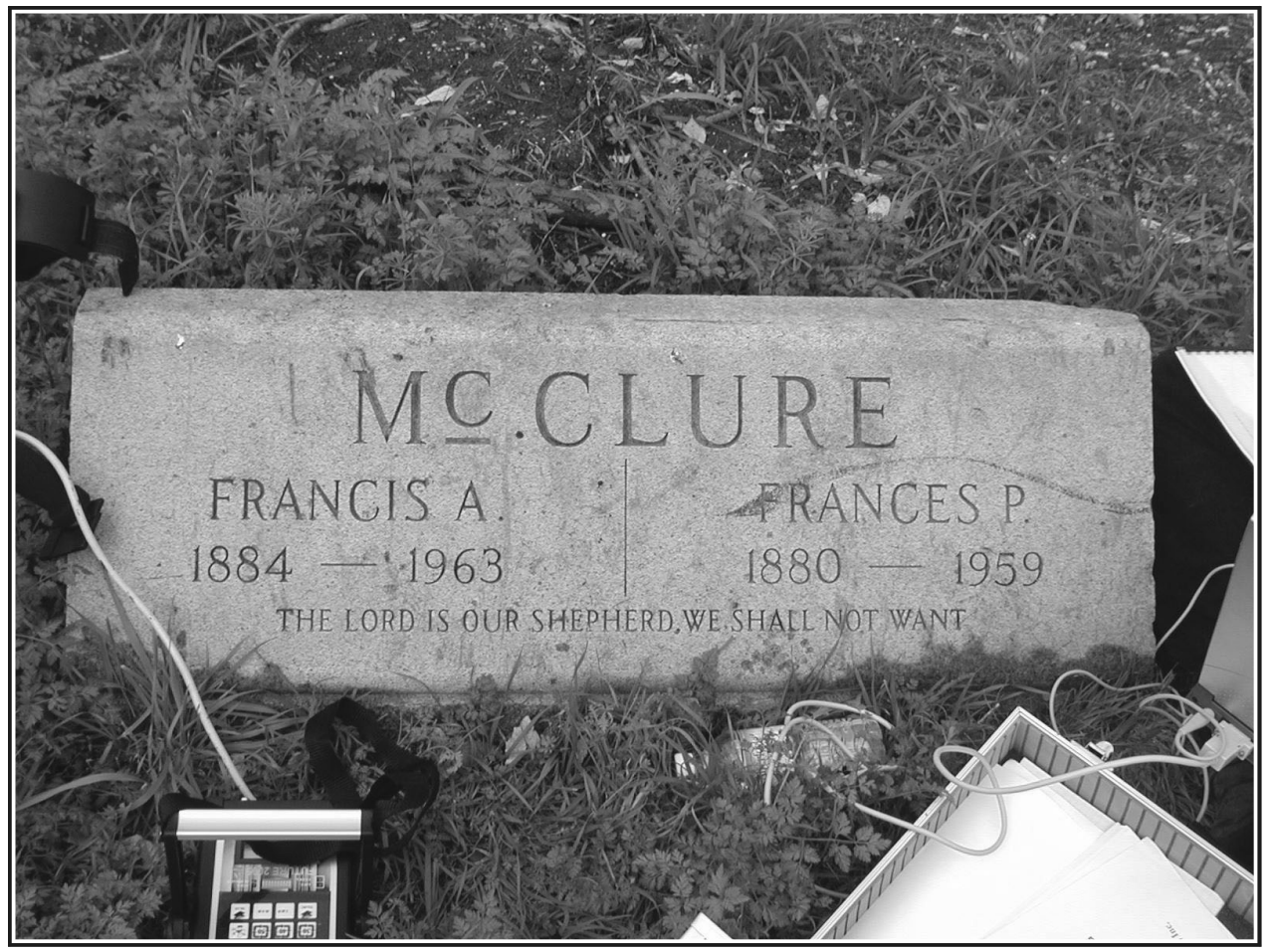

Figure A-10. The Francis A. and Frances P. McClure headstone. 
Appendix B

\section{Boring Logs Reproduced from Arias and Kezar Geotechnical Report}



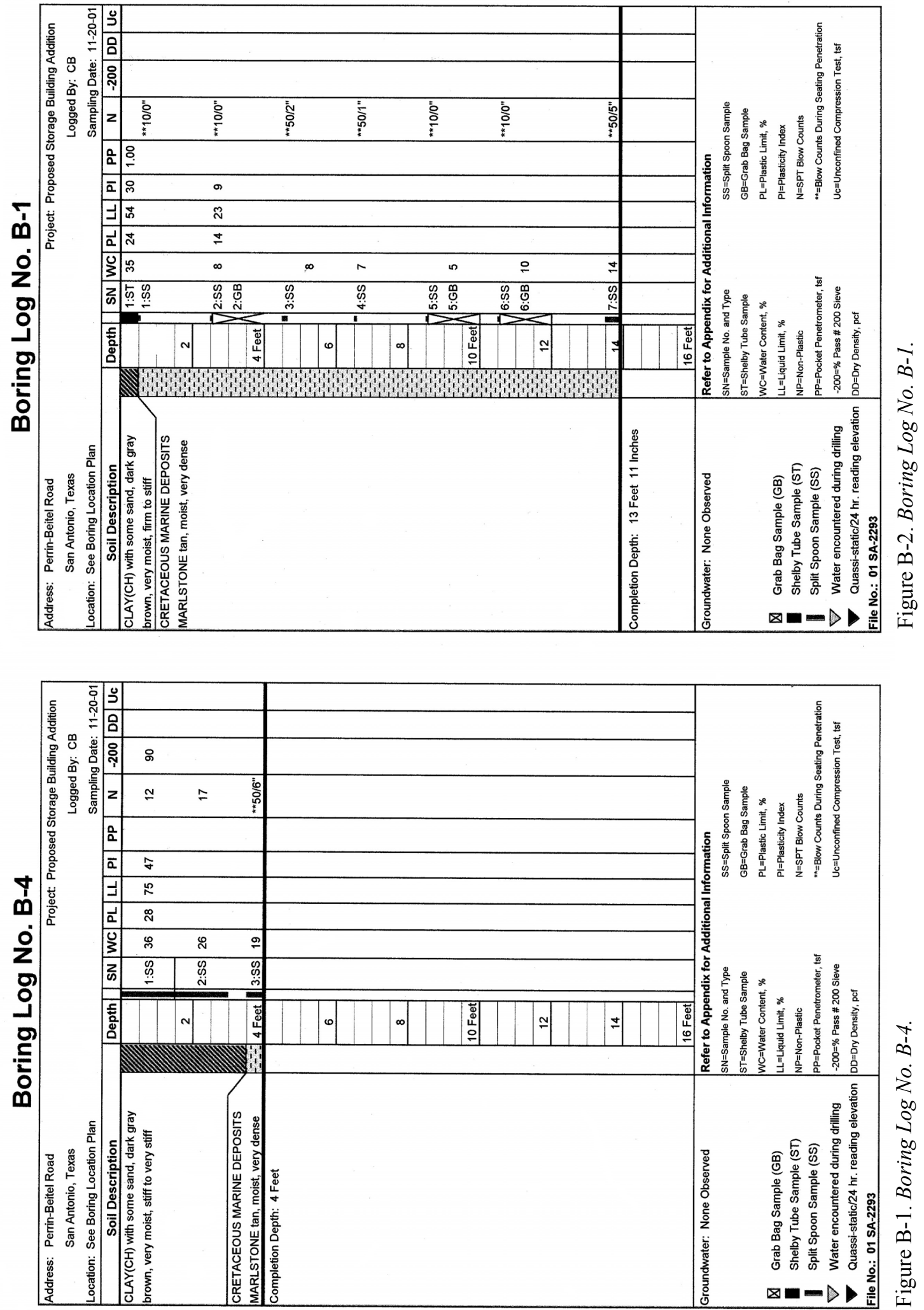

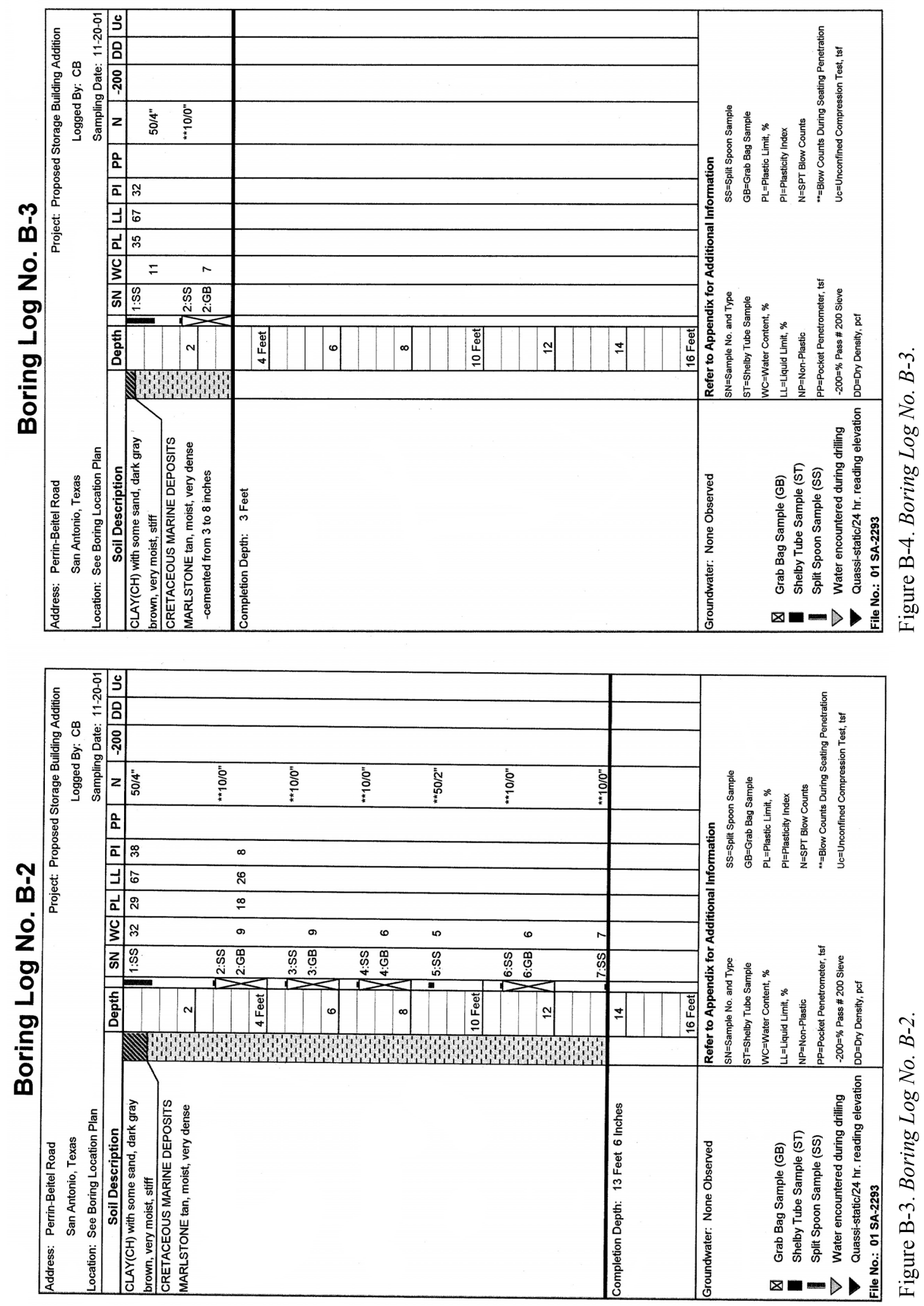


\section{Appendix C}

\section{Survey of Perrin Family Gravesite Tract conducted by Pape-Dawson Engineers}




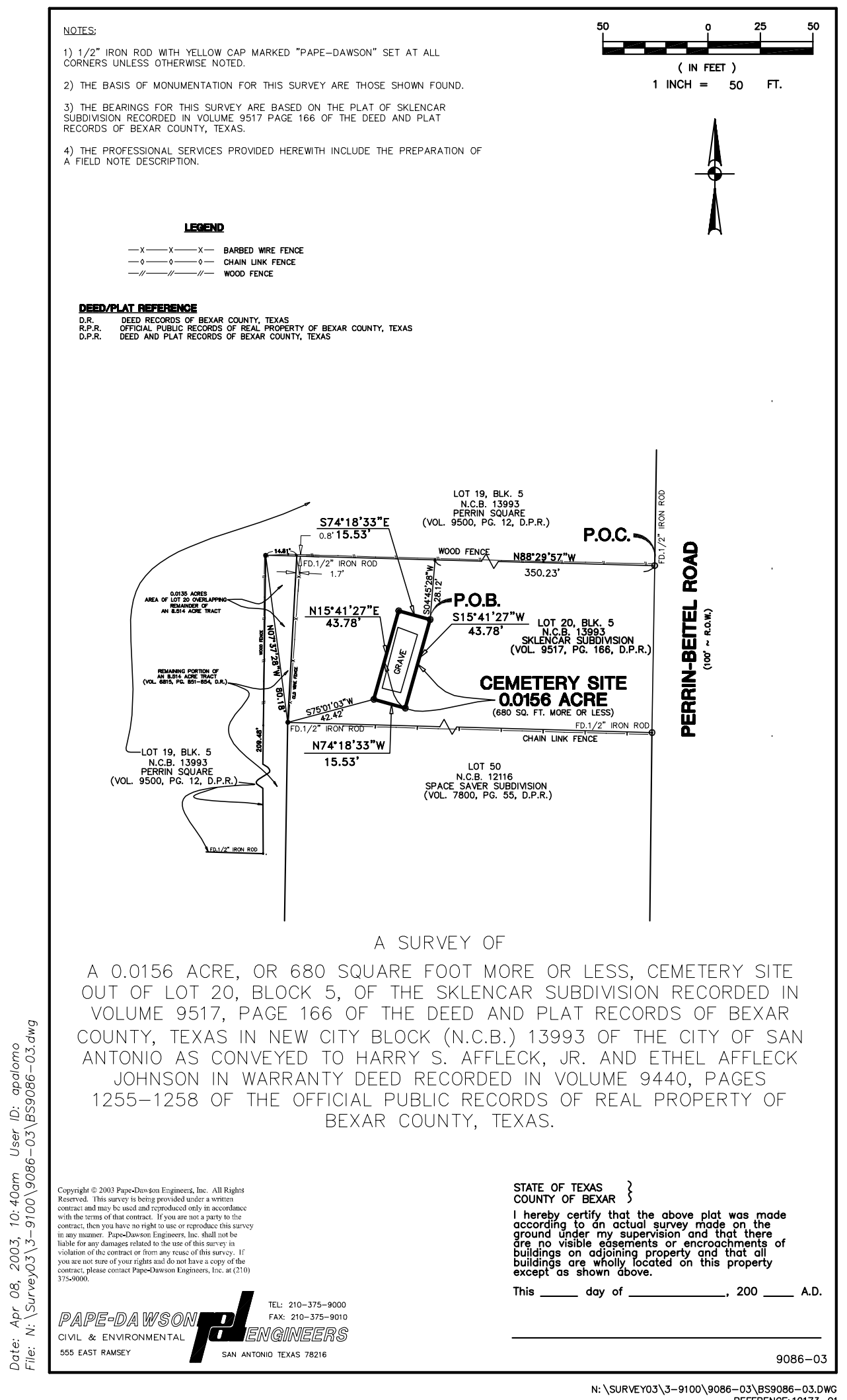




\section{FIELD NOTES}

FOR

A 0.0156 acre, or 680 square foot more or less, Cemetery Site out of Lot 20, Block 5, of the Sklencar subdivision recorded in Volume 9517, Page 166 of the Deed and Plat Records of Bexar County, Texas in New City Block (N.C.B.) 13993 of the City of San Antonio being the same tract of land conveyed to Harry S. Affleck, Jr. and Ethel Affleck Johnson in Warranty Deed recorded in Volume 9440, Pages 1255-1258 of the Official Public Records of Real Property of Bexar County, Texas and being more fully described as follows:

COMMENCING: At a found $1 / 2$ " iron rod, said point being on the west line of PerrinBeitel, a 100-foot right-of-way, the southeast corner of Lot 19, Block 5, N.C.B. 13993, Perrin Square Subdivision, recorded in Volume 9500, Page 12, of the Deed and Plat Records of Bexar County Texas, the northeast corner of the herein described tract;

THENCE: $\quad$ N $88^{\circ} 29^{\prime} 57^{\prime}$ ' W, along and with the south line of said Lot 19, a distance of 350.23 feet, to a point;

THENCE: $\quad$ S $04^{\circ} 45^{\prime} 28^{\prime \prime} \mathrm{W}$, departing the south line of said Lot 19, a distance of 28.12 feet, to a set $1 / 2$ " iron rod with a yellow cap marked "Pape Dawson", the northeast corner and POINT OF BEGINNING of the herein described tract;

THENCE: $\quad$ S $15^{\circ} 41^{\prime} 27^{\prime \prime} \mathrm{W}$, a distance of 43.78 feet to a set $1 / 2$ " iron rod with a yellow cap marked "Pape Dawson", the southeast corner of the herein described tract;

THENCE: $\quad \mathrm{N} 74^{\circ} 18^{\prime} 33^{\prime}$ 'W, a distance of 15.53 feet to a set $1 / 2$ " iron rod with a yellow cap marked "Pape Dawson", the southwest corner of the herein described tract, from which a found $1 / 2$ " iron rod bears $S 75^{\circ} 01^{\prime} 03^{\prime \prime} \mathrm{W}$, a distance of 42.42 feet, at the southwest corner of said Lot 20;

THENCE: $\quad \mathrm{N} 15^{\circ} 41^{\prime} 27^{\prime \prime} \mathrm{E}$, a distance of 43.78 feet to a set $1 / 2$ " iron rod with a yellow cap marked "Pape Dawson", the northwest corner of the herein described tract;

THENCE: $\quad$ S $74^{\circ} 18^{\prime} 33^{\prime \prime} \mathrm{E}$, a distance of 15.53 feet to the POINT OF BEGINNING, and containing 0.0156 acres in the City of San Antonio, Bexar County, Texas, said tract being described in accordance with a survey made on the ground and a survey map prepared by Pape Dawson Engineers Inc.

Prepared By: $\quad$ Pape Dawson Engineers Inc.

Job No.: $\quad$ 9086-03

Date: $\quad$ April 4, 2003

Doc Id.: N:ISurvey03\3-9100\9086-03\9086-03FN.doc 